580.5

FB

V. 4:2-9

1919-1929

cop. 2 


Field Museum of Natural History.

Publication 204.

Botanical Series.

Vol. IV, No. 2.

\section{REVISION OF THE NORTH AMERICAN SPECIES OF XANTHIUM}

BY

Charles Frederick Millspaugi

AND

Earl Edward Sherff.

Charles Frederick Millspaugh

Curator, Department of Botany.

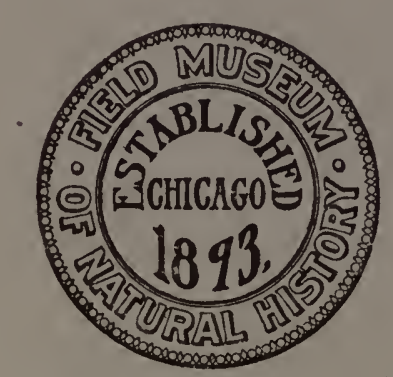

THE LIBRARY OF THE
J'L 241943
UAIVERSITY OF ILINOIS
Chicago, U. S. A.
April, rgrg.

Dup. 

Field Museum of Natural History.

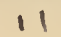

Publication 204.

Botanical Series.

Vol. IV, No. 2.

\section{REVISION OF THE NORTH AMERICAN SPECIES OF XANTHIUM}

BY

Charles Frederick Millspaugh

AND

Earl Edward Sherff.

Charles Frederick Mullspaugh

Curator, Department of Botany.

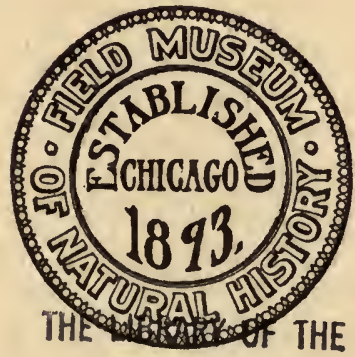

$$
\text { JU'L } 241943
$$

UNIYERSITY OF ILINOIS

Chicago, U. S. A.

Issued April 30, I9r9. 


\title{
REVISION OF THE NORTH AMERICAN SPECIES OF XANTHIUM
}

\author{
CHARLES F. MILLSPAUGH, M.D., and EARL E. SHERFF, Ph.D
}

The monographic study of the genus Xanthium is involved in difficulties not only as to bibliography but also as to species concept. Thanks to the kind and hearty co-operation of various botanists, we have been able to settle very satisfactorily the numerous matters of bibliography. The species concept in Xanthium, however, must long remain a perplexing problem. In temperate regions, the plants do not mature their fruits sufficiently for exact determination until after frost comes and the majority of collecting botanists have ceased their field-work. This renders good material in herbaria scanty in quantity and inadequate in quality. Some of the species are known to exhibit most striking variations in fruiting characters, - variations that with many botanists would be taken to represent varieties or subspecies. In fact, several of the more pronounced of these forms have been made the basis of new species by certain authors, notably Greene (e.g., $X$. acutum, $X$. affine, $X$. californicum, $X$. glanduliferum). In the present monograph the writers have endeavored to be neither hasty in the proposal of new specific names nor radical in the reduction of old names to synonomy. The taxonomic treatment has been made to accord as strictly as possible with the observed data. We have retained several of the less well known species (e.g., X. acerosum, X. cylindricum, $\mathrm{X}$. globosum, species that with some botanists might be reduced to varietal or subspecific rank), because we have felt that only after further field observations and breeding tests can satisfactory conclusions as to their true status be reached.

Many of the numerous references in literature have necessarily been omitted in the main body of our text: for a large number of these references the reader is directed to De Candolle's Prodromus (6:522-524. 1836) and to Wallroth's Monograph of Xanthium (Beitr. Bot. III: 229-244., I844). Since the publications of De Candolle and of Wallroth, several other more or less extended studies of the genus have been made: In I893, Rowlee (Bull. Torr. Bot. Club 20: 10), writing upon the seedling development of Xanthium, noted that "both 
achenes in a single head frequently germinate, usually not at the same time however, so the seedlings will be at two stages of growth." In I 895, Arthur (Proc. Soc. Prom. Agricult. Science r6:70-79) remarked upon the inequality in size between the two achenes in the burs of Xanthium and the delayed germination of the smaller one. Arthur stated (loc. cit., p. 77) that "the bur with its contents is the physiological equivalent of an achenium." Later, Masterman (Ohio Nat. I:69-70. I90I) published observations upon several thousand specimens which showed results directly opposite to those of Arthur (thus, of 3000 burs, 275I produced two plants each, at the same time).

In 1906, Crocker (Bot. Gaz. 42:265-29I), writing upon delayed germination of seeds, treated of the physiological conditions of delayed germination of Xanthium seeds. In I908, Bitter, who had been inspired by the early observations of Lasch (Bot. Zeitung I4:409. I856) to undertake careful cultural researches upon certain species of Xanthium, was able to describe several pronounced races of $X$. italicum and of $\mathrm{X}$. spinosum. His numerous attempts at crossing $\mathrm{X}$. spinosum with species of the Section Euxanthium had been in vain. Thus he states (Abhandl. Nat. Ver. Bremen I9 ${ }^{\mathrm{II}}: 29 \mathrm{I}$. Ig08): "Bastarde lassen sich nach meinen Erfahrungen zwischen den Euxanthien leicht erzielen, wenigstens habe ich $\mathrm{X}$. macrocarpum DC. und X. italicum erfolgreich mit X. strumarium gekreuzt; dagegen waren meine vielfachen Versuche, $\mathrm{X}$. spinosum mit Euxanthien zu kreuzen, erfolglos."

Somewhat later in the same year, Thellung (Verhandl. Bot. Verein Brandenb. $5^{\mathrm{II}}$ : ${ }^{137-15}$; see also Mitteil. Bot. Mus. Univ. Zurich 58: 505-5I2. I9I2) published a very comprehensive survey of the botanical literature relating to X. orientale L. and X. echinatum Murr. Thellung's concept of these two species was so broad that his treatment of them was stretched almost into monographic proportions. His work in the herbarium seems to have been far less extensive than his work in the library. We are not able otherwise to explain many of his numerous equations of species with each other,- species which in several instances are so strikingly unlike in fruit characters that we are entirely unable to accept their reduction to synonomy by Thellung.

In IgI I, Shull (Bot. Gaz. 52:453-477) published his investigations upon the oxygen minimum and the germination of Xanthium seeds. Later, in I914, the same writer (Bot. Gaz. $57: 64-69$ ) presented further data obtained along these lines. Likewise in I9r4, Dalbey (Kansas Univ. Science Bull. $9: 57-65$ and pls. 16-22) enumerated various anatomical characters of $\mathrm{X}$. pennsylvanicum, $X$. americanum $[=\mathrm{X}$. chinense] and $X$. globosum. She states that these three species "present some striking external characteristics, while in their anatomy there 
are some definite but minor differences which might prove of uncertain value in classification." The following year Farr described and illustrated the origin of the inflorescences of Xanthium (Bot. Gaz. 59: I36-I48 and pl. Io. I9I5). Several interesting conclusions are stated by Farr. Among these, we note (loc. cit., p. 145) that the "terminal heads became staminate, because the vascular supply was inadequate to compensate for the excessive transpiration, and hence the pistils have aborted"; also that "the bur is a modified capitulum, differing from the typical head of Compositae chiefly in the two depressions in the receptacle. These pits originate through a temporary arrest of development, which may possibly be attributed to contact with the tips of the recurved involucral bracts. This recurving of the bracts may be the result of limited space due to the subtending structures."

Throughout the prosecution of our own study, we have received the most generous assistance from other botanists, both in America and in Europe. It is with a sense of genuine pleasure that we express our gratitude for such help, which usually consisted either in loaning herbarium material, in furnishing photographic reproductions of descriptions and plates, or in extending to us various herbarium facilities. Chief among those to whom we are thus indebted are Prof. Augusto Béguinot, Director, R. Orto Botanico, Padua; Dr. Ezra Brainerd of Middlebury, Vermont; Dr. N. L. Britton, Director of the New York Botanical Garden; Miss Mary A. Day, Librarian of Gray Herbarium; the late M. Casimir De Candolle, of Geneva; Mrs. Nellie F. Flynn of Burlington, Vermont; Dr. J. M. Greenman, Curator of the Herbarium of the Missouri Botanical Garden; Dr. H. M. Hall, of the University of California; Professor James M. Macoun, of the Canadian Geological Survey; Mr. Wm. R. Maxon, Associate Curator of the United States National Herbarium; Dr. George T. Moore, Director of the Missouri Botanical Garden; Dr. Julius A. Nieuwland, of the University of Notre Dame (in charge of the Greene Herbarium); Sir David Prain, Director of the Royal Botanical Gardens at Kew; Dr. A. B. Rendle, of the British Museum of Natural History; Dr. B. L. Robinson, Curator of Gray Herbarium; Dr. C. A. Shull of the University of Kentucky, and Miss Ethelyn M. Tucker, Librarian of the Arnold Arboretum.

Upwards of two hundred phutographs were made of the more important specimens examined in other herbaria during the progress of the work. These, together with full data, are deposited in the herbarium of this Museum. 
ABBREVIATIONS USED FOR HERBARIA

Hb. Calif. Herb. University of California

Hb. Can.

Herb. Canadian Geological Survey

Hb. Chi.

Herb. University of Chicago

Hb. Field

Herb. Field Museum of Natural History

Hb. Mo.

Herb. Missouri Botanical Garden

Hb. N. Y.

Herb. New York Botanical Garden

Hb. U. S.

United States National Herbarium

Xanthium (Tourn.) Linn. Sp. P1. 987. I753

[Tourn. Instit. tab. 252, I 700. Linn. Gen. P1. 424, I 754]

Herbae annuae, ramosae, crassae, plerumque scabridae aut spinosae, monoicae, sporadicae. Folia alterna, petiolis tenuibus petiolata, plus minusve lobata aut rarissime inciso-divisa, plerumque punctis resinosis parvis numerosis punctata. Capitula discoidea, homogama. Involucra mascula summa, subglobosa, multiflora, bracteis liberis I-3-seriatis; receptaculo cylindraceo, paleaceo; corollis tubulosis, clavatis, apice 5-dentatis; staminum filamentis monadelphis, antheris liberis, conniventibus, basi ecaudatis, appendicibus apicalibus incurvato-mucronatis; stylo simplici, tenue, ad apicem plus minusve dilatato; achaenio rudimentario. Involucra feminea gamophylla, clausa aut rare subclausa, cylindrica aut ovoidea aut etiam subglobosa, hamato-aculeata aut rarissime simpliciter aculeata, ad apicem 2-rostrato (in Sect. II, Acanthoxanthio, uno aut duobus rostris saepius absentibus); intus 2-loculare; corollis absentibus; styli ramis e rostris exsertis; acheniis linearibus aut etiam ovatis, compressis, plus minusve crassis, ad apicem tenuiter rostratis, levibus, singulis in loculis singulis inaequalibus involucri maturatis et manentibus.

\section{Clavis Generis}

Folia attenuata utrinque; axillis spinis tripartitis munitis; aculeis ad apicem cygneo-hamatis

I. X. spinosum

Folia cordata, ovata aut subtriangulata; axillis inermibus; aculeis ad apicem rectis aut simpliciter hamosis:

Fructus maturi plerumque maximi, aculeis et rostris adjectis $2.8-4 \mathrm{~cm}$. longi et $2-3 \mathrm{~cm}$. lati:

Aculei plerumque arcuati et corniformes, subcrassi:

Aculei saepius numerosi et conferti, teretes $2 \mathrm{I}$. X. campestre

Aculei plerumque pauciores et remoti aut subremoti, infimi ad faciem ventralem canaliculati

Aculei non perspicue arcuati nisi ad apicem hamosum, tenues

I9. X. oviforme

20. X. speciosum

Fructus maturi minores:

Aculei pauci et remoti (20-50):

Fructus magni, corpore $1.5-1.7 \mathrm{~cm}$. longo et $6-7 \mathrm{~mm}$. lato; aculeis 8-10 $\mathrm{mm}$. longis

Io. $\mathrm{X}$. cenchroides 
Fructus minores:

Fructi maturi subvirides

Fructi maturi plerumque flavidi aut rubri:

Fructus corpus anguste cylindricum:

Aculei recti ad apicem hamosi $8 . X$. leptocarpum

Aculei dimidio supero flexi

7. X. curvescens

Fructus corpus ovatum aut oblongum:

Aculei cartilaginei, crassi, fructus corpore circ. $8 \mathrm{~mm}$. crasso

Aculei subtenues, fructus corpore pler-

Aculei plures: umque $5^{-6} \mathrm{~mm}$. crasso

I3. X. calvum

9. X. Wootoni

Fructi glabri aut subglabri:

Fructus corpus plerumque cylindricum:

Folia acute lobata; fructibus venustis; aculeis tenuibus, $2.5-3.5 \mathrm{~mm}$. longis

4. X. cylindricum

Folia subobtuse lobata; fructibus crassioribus; aculeis crassioribus et saepius $3.5^{-7} \mathrm{~mm}$. longis

12. X. pennsylvanicum

Fructus corpus plerumque crasso-ovoideum aut subglobosum:

Rostra elongata (6-9 mm. longa); species mexicana et austro-americana

Rostra non elongata (3-4 mm. longa); species boralior

Fructus corpus ovato-oblongum:

Aculei breves (saepius circ. $2 \mathrm{~mm}$. longi), basi dilatati

Aculei longiores, basi non perspicue dilatati:

I5. X. australe

5. X. globosum Rostra brevia (circ. $2 \mathrm{~mm}$. longa), crassa

Rostra longiora (3-6 mm. longa), tenuiora:

2. X. strumarium

Aculei conferti, arcuati:

Quidam aculei ad fructus rostra longissimi (8-10 $\mathrm{mm}$.); rostris $5-7 \mathrm{~mm}$. longis II. X. inflexum Aculei aequales aut subaequales (4-6 $\mathrm{mm}$. longis); rostris $3.5-5 \mathrm{~mm}$. longis $6 . \mathrm{X}$. arcuatum

Aculei remotiores, recti

Fructus plus minusve setosi, hispidi aut pilosi:

Aculei fructuum maturorum dense, longe et molliter fuscopilosi

I8. X. acerosum

Aculei fructuum maturorum setosi aut hispidi sed non vere longo- et molli-pilosi:

Fructus 8-1 $2 \mathrm{~mm}$. longi; aculeis circum $2 \mathrm{~mm}$. longis (specie maximam partem gerontogaea) 2. X. strumarium

Fructus et aculei longiores:

Aculei valde hispidi:

Corporis latitudo quam longitudo

circ. dimidio minor

Corporis latitudo etiam minor

I6. $X$. echinatum

I $7 . X$. italicum 
Aculei non valde hispidi.

Quidam aculei ad fructus rostra longissimi (8-10 $\mathrm{mm}$.)

II. X. inflexum

Aculei aequales aut subaequales:

Corpus globoso-ovatum, rostris elongatis

I 5. X. australe

Corpus plerumque angustius, rostris non perspicue elongatis I2. X. pennsylvanicum

Sect. I. ACANTHOXANTHIUM DC. Prodr. 5:523.1836; Acanthoplia Wallr., Beitr. Bot. II : 24I. 1844; Acanthoxanthium Fourr., pro genere, Ann. Soc. Linn. Lyon., N. Ser. 17 : I10. 1869. Involucri fructigeri rostrum saepius unicum aut nullum; fructibus apice conniventibus, clausis; spinis validis ad basim foliorum; foliis numquam cordatis sed basi cuneatis.

r. Xanthidm spinosum Linn. Sp. P1. 987. 1753.

Xanthium xanthocarpon Wallr. Beitr. Bot. I" ${ }^{\mathrm{I}}$ :24I. I844.

Acanthoxanthium spinosum Fourr. Ann. Soc. Linn. Lyon., N. Ser. I7 : IIO. I869.

Caulis pubescens, ramosus, erectus aut ascendens, $3^{-12} \mathrm{dm}$. altus. Folia lanceolata aut ovato-lanceolata, petiolata, utrinque acuminata aut acuta, 2-4-lobata aut supera integra, infra et ad venas supra canescentia, petiolis adjectis $4-12 \mathrm{~cm}$. longa, axillis spinis gilvis tripartitis usque ad $2.5 \mathrm{~cm}$. longis munita; petiolis $0.5^{-2} \mathrm{~cm}$. longis. Fructus (P1. VII, f. I; P1. VIII, ff. I-3) oblongo-cylindrici, plerumque flavido-virides, pubescentes; rostris tenuibus, levibus, acribus, circ. $3 \mathrm{~mm}$. longis, plerumque uno et saepe etiam duobus absentibus; aculeis distinctis aut remotis, ex apice cygneo-curvato in hamum inflexum quartam aculei partem desinentibus. ${ }^{1}$.

Distribution: Now generally distributed almost throughout the United States; found also in South America, where probably native, ${ }^{2}$ central Europe, "western Asia, southern Africa and in Australia."

SPECIMENS EXAMINED:" NEw YoRK: without locality or date, M. Ruger (Hb. Mo. 720720). New Jersey: Camden, Aug., 1878, Isaac C. Martindale (Hb. Mo. 720837). District of Columbia: vicin. of Washington, waste ground, E. S. Steele 43 (Hb. Mo. 85567 and 85568). Virginia: Bedford County, A. H. Curtis 3472 (Hb. Mo. 85569); Wythe County, Reed Creek, at base of lower rocks, July 23 , I892, John K. Small (Hb. Mo. 85570). FxorIDA: Apalachicola, without date, Dr. A. W. Chapman (Hb. Mo. 783796). Illinors: Mound City,

1 It may be remarked that in the description we have omitted all reference to achene characters. As the characters of the achene can not be described satisfactorily from fruits not known to be mature, and as thoroughly mature fruits have not, in all species, been available for dissection, it has been deemed best to omit these characters from all of the specific descriptions.

${ }^{2}$ Cf. Thellung, Mitteil. bot. Mus. Univ. Zürich $58: 505$. 1912.

Many omitted here for lack of space. 
without date, George Vasey (Hb. Field I3470). Kentucky: Bowling Green, Oct., 1899, Sadie F. Price (Hb. Mo. 85573). Tennessee: Knoxville, vacant lots, July, I893, A. Ruth (Hb. Mo. 720836). MissouRI: St. Louis, Oct. 23, I893, H. Eggert (Hb. Mo. 85575, 720560 and 720835). Texas: Handley, Sept. 23, I902, J. Reverchon (Hb. Mo. 85580). New Mexico: near Pecos, Paul C. Standley 5150 (Hb. Mo. 85582 ; Hb. N. Y.). Nevada: Verdi, Oct., I893, C. F. Sonne (Hb. Calif. I96334). Arizona: Prescott, David Griffiths 7344 (Hb. Mo. 85583). Vancouver Island: Nanaimo, July 7, I887, John Macoun (Hb. N. Y.). Washington: Walla Walla, July, 1898 , Savage, Cameron and Lenocker (Hb. Mo. 85584). California: Los Angeles, Le Roy Abrams 4I8I (Hb. Calif. I49138; Hb. Mo. 85589; Hb. N. Y.); Sherman, Ernest Braunton 731 (Hb. Calif. 54I78); vicin. Mendocino, H. E. Brown gIg (Hb. N. Y.); near Yreka, Geo. D. Butler 99I (Hb. Calif. 163874); Colusa County, J. Burtt Davy 4277 (Hb. Calif. 36807); near Durham, roadsides and fields, $A$. A. Heller 12655 (Hb. Mo. 802945); San Simeon Bay, July 22, 1876, Dr. Edw. Palmer (Hb. Mo. 85587); Haywards, Nov. I4, I893, Ivar Tidestrom (Hb. Calif. 36806); Avalon, Santa Catalina Isl., Aug., I902, Blanch Trask (Hb. N. Y.).

Wallroth (loc. cit.) founded his Xanthium xanthocarpon upon a specimen by Beyrich, from fields between Staunton and Charlottesville, Virginia. The distinctive characters tabulated in his description are entirely too inconstant, however, to serve in distinguishing the species from true $X$. spinosum $L$. Thus, for example, Wallroth described the beaks as unequal, the larger one twice stouter than the prickles: ("Rostris inaequalibus, majore aculeis duplo validiore"). In the nearly two hundred specimens of $\mathrm{X}$. spinosum which we have examined, from North America, we have seen several that matched Wallroth's description in these and other respects precisely. Nevertheless these specimens were but slight variations from the more common, shortbeaked form regarded by Wallroth as representing the true Xanthium. spinosum L.

Sect. II. EUXANTHIUM DC. Prodr. 5 : 523. I836; Anoplia Wallr. Beitr. Bot. $\mathrm{I}^{\mathrm{II}}$ : 229. I844. Involucri fructigeri rostra apice nunc recta (Tribus I. Orthorrhyncha Wallr. loc. cit.), nunc in hamum varie inflexum desinentia (Tribus II. Campylorrhyncha Wallr., loc. cit.), nunc hiatu longitudinali magis minusve contracto reclusa vel teretia, nunc transversim fissa, veluti bivalvia; caulibus erectis saepius purpureo-maculatis; foliis dentatis; spinis ad basim foliorum nullis. 
2. Xanthium Strumarium Linn. Sp. P1. 987. I753.

Xanthium priscorum Wallr. Beitr. Bot., I ${ }^{\mathrm{II}}: 227$. 1844. (nom. semi-nudum.)

Xanthium antiquorum Wallr. loc. cit. 229

Xanthium strumarium L. var. antiquorum (Wallr.) Ball, Jour.

Linn. Soc. I6 : 503. 1878 .

Xanthium abyssinicum Wallr. loc. cit. 230.

Xanthium discolor Wallr. loc. cit. 232.

Xanthium Roxburghii Wallr. loc. cit. 233.

Xanthium brevirostre Wallr. loc. cit. 235 .

Caulis subramosus, pubescens, $0.4^{-1.5} \mathrm{~m}$. altus. Folia triangulatodeltoidea et ad basim truncata aut subcordata, 3-5-lobata, utrinque pilis adpressis strigosis vestita et concoloria, petiolis adjectis $0.6-2.5 \mathrm{dm}$. longa; petiolis laminas subaequantibus aut excedentibus. "Fructuum (Pl. VII, f. 2; P1. VIII, ff. 4-8) corpus ovoideum, aut tumidum et subglobosum, plerumque subviride, pubescens, $0.8-1.4 \mathrm{~cm}$. longum; rostris versus apicem rectis aut incurvatis, I-2 $\mathrm{mm}$. longis, saepius distantibus; aculeis rectis, ad apicem hamosis, supra glabris, infra plus minusve pubescentibus, circ. 2 (rarius 3 ) $\mathrm{mm}$. longis.

Distribution: Adventive in Massachusetts and California; native of the north-temperate and tropical regions of the Eastern Hemisphere.

Specimens eXamined: Massachusetts: Revere, Crescent Beach, Oct. 20, I9I 2, M.L.Fernald (Hb. Gray). California: Colorado Desert, Cameron Lake, Mar. 28, I9or, T.S. Brandegee (Hb. Calif. I3r246).

We have already (Field Mus. Bot. $4: 2$. I918) noted the collection of genuine X. strumarium in North America, by Fernald, in I912. It is of interest to note that, several years earlier, this species was collected in the extreme southern part of California, by Brandegee. We have not seen the species from elsewhere in America. ${ }^{1}$

In 1830 Rafinesque listed (Med. F1. $2: 275$ ) " 2 native species Xanthium crassum and undulatum Raf. mistaken for X. strumarium and orientale by authors." Thus Rafinesque is seen to have realized, at an early date, that the common forms of Xanthium in America were not referable to $X$. strumarium and X. orientale (see p. 26, foot-note). Rafinesque's two names appear to have been ignored, or indeed overlooked, by botanists since then. But obviously these names can be treated only as nomina nuda, for their precise application to definite American species is impossible. Characteristically, in this connection, Rafinesque fails to mention his own Xanthium maculatum, described, in detail, from the eastern United States eleven years before. There exists, in Gray Herbarium, a good co-type of $X$. abyssinicum Wallr. (W. Schimper 1343). This specimen we are entirely unable to separate

${ }^{1}$ At least as an escaped plant. We have seen good fruiting material however, raised by Dr. John M. Adams at Cincinnati, Ohio, in 1918, from seed imported with soy-beans from Manchuria (specimen in Hb. Ohio Agr. Exp. Station). 
from X. strumarium L.; in the same herbarium is a specimen (Kotschyi iter Nubicum 3I9, ad ripas Nili albi prope Chartum in provincia Sennar, Mar. 4, 1840) which has slightly longer and more numerous prickles, these more hirsute below than in most other specimens. This is the form cited by Wallroth for his $X$. antiquorum. ${ }^{1}$ It is matched very well by a fine specimen in the Herbarium of Field Museum (Fred S. Meyers 215, waste places, Jaffa, Aug. 2, I902, Hb. Field I62920) coming from Palestine. The distinctions emphasized appear to us, however, too slight and inconstant to warrant maintaining $X$. antiquorum apart from $\mathrm{X}$. strumarium. Likewise, after examining a number of specimens from India (mainly in $\mathrm{Hb}$. Gray) we are convinced that $X$. discolor Wallr., $X$. Roxburghii Wallr. and $X$. brevirostre Wallr. are merely forms of $\mathrm{X}$. strumarium L. (as indeed they were regarded by Hooker, Fl. Brit. Ind., $3: 303$. I88I). ${ }^{2}$

3. Xanthium chinense Mill. Gard. Dict. Edit. VIII, No. 4. I768. Xanthium chinense Mill. Abridg. Gard. Dict. Edit. VI, No. 4. I77.

Xanthium occidentale Bertol. Lucubr. Herb. 38 . I822.

Xanthium macrocarpum var. glabratum DC. Prodr. $5: 523$. 1836. ex. descr.

Xanthium pungens Wallr. Beitr. Bot. $\mathrm{I}^{\mathrm{Ir}}: 23 \mathrm{I}$. $\mathrm{I} 844$.

Xanthium longirostre Wallr. loc. cit. 237; Britton Fl. Bermuda 384, f. 4 I7. I9I8.

Xanthium glabratum Britt. Man. 9I2. I901. ${ }^{3}$

1 Xanthium priscorum Wallr. (loc. cit. 227). Wallroth used the name $X$. priscorum in his clavis, accompanying it with a short diagnosis; but in the main body of his work and also in the introduction (pp. 22I and 229) he had changed the name to $X$. antiquorum. His retention of the name $X$. priscorum was clearly through an oversight. We may note a similar error in regard to his $X$. eriocarpon (which is referable to $\mathrm{X}$. ambrosioides Hook. \& Arn., for which species Wallroth merely made a new, and in his opinion, more accurate name; we have seen various excellent specimens in $\mathrm{Hb}$. Gray and Hb. N. Y.). Wallroth at first (loc. cit. 229) advanced this species in his clavis under the name $X$. leucocarpon, with a short diagnosis; but in the main body of his work (p.242) he had changed the name to $X$. eriocarpon.

' Xanthium inaequilaterum DC., a species with smaller fruits $(5-6 \mathrm{~mm}$. long exclusive of the beaks), originally described from material collected near Buitenzorg, Java, is similar to $X$. strumarium, but its smaller fruits are very distinctive. Several good (topotypic) fruiting specimens exist in $\mathrm{Hb}$. Gray (Zollinger, Batavia, Java, in 1849; Teysmann, ex horto bogoriensi, Buitenzorg, Java, in 1869). These are remarkably uniform and appear to indicate that the species $X$. inaequilaterum DC. is entirely separate from X. strumarium L.

A number of other species of Xanthium have been described from the Eastern Hemisphere that undoubtedly are mere forms of $\mathrm{X}$. strumarium; however, as opportunity has been lacking to examine authentic material, their names have been omitted from our list of synonyms.

'Xanthium canadense of Rowlee, not Miller, Bull. Torr. Bot. Club 20 : 10, ff. g-m. 1893.

?Xanthium carolinense Dill. ex MacMillan, Geol. Nat. Hist. Surv. Minn. Bot. I : 535. 1892. We have not seen the original work of Dillenius, cited by MacMillan, for this reference.

Xanthium strumarium of Millsp. \& Chase, Field Mus. Bot. $3: 87, \mathrm{f} .1904$.

Xanthium strumarium of Britton \& Brown, Ill. Fl. $3: 298$, f. 3599. I 898 . See also footnote, p. 40. 
Caulis scaber, $0.3^{-1}$ (aut etiam-2) m. altus. Folia late triangulatoorbiculata, acute 3-5-lobata, subacute dentata, ad basim cordata aut reniformia, plerumque submembranacea, utrinque concoloria et pilis setosis adpressis brevissimis vestita, petiolis adjectis $\mathrm{I}-3 \mathrm{dm}$. longa, inferiora interdum $2.5 \mathrm{dm}$. lata, petiolis laminis subaequantibus. Fructus (P1. VII, f. 3; P1. VIII, ff. 9-15) ovoidei aut fusiformes, calvescentes, aequaliter et conformiter aculeati, fusco-virides aut rubescentes; corpore sparsissime brevi-pubescenti, glanduloso, 0.9- $1.5 \mathrm{~cm}$. longo (rarius longiore); rostris rectis aut arcuatis, infra pubescentibus, ad apicem inflexis aut infirme hamosis, 3-6 mm. longis; aculeis glabratis aut ad basim sparsim glanduloso-pubescentibus, rectis, ad apicem hamosis, rostris aequantibus.

Distribution: Massachusetts, Ontario and Nebraska, to Florida, Texas and California (where very rare); eastern Mexico and throughout the West Indies.

Specimens examined: ${ }^{1}$ Massachusetts: Wayland, Sept. Io, igog, M. L. Fernald (Hb. Gray). Connecticut: Goshen County, wet ground, Sept. I8, 1905, C. H. Bissell (Hb. Gray); West Hartford, border of pond, Oct. 14, 1906, idem (Hb. Gray). New YoRK: Long Island, Lakeville, waste place, Sept. $25, \mathrm{I} 899, J$. R. Churchill (Hb. Gray) Canton, banks of Grass River, Mrs. Orra Parker Phelps 989 (Hb. Gray); Ogdensburg, along banks of St. Lawrence River, eadem I2I5 (Hb. Gray; an unique form with abnormally large fruits having bodies $\mathrm{I} .9-2.4 \mathrm{~cm}$. long and 7.5-9.5 mm. thick). Pennsylvania: near Philadelphia, John $\mathrm{H}$. Redfield 3475 (Hb. Mo. 85397). Maryland: Plummer's Island, in Potomac River, near Cabin John, Thomas H. Kearney 193 (Hb. U. S. 640356); shore of Chesapeake Bay, south of Havre de Grace, George H. Shull 392 (Hb. Gray; Hb. Mo. 85399). District of Columbia: Washington, Charles L. Pollard $7 I 8$ (Hb. U. S. 234642). Virginia: Bedford County, Oct. Io, I87 , A. H. Curtiss (Hb. Gray); Altavista, waste land, Juliet Fauntleroy 677 (Hb. U. S. 754995). NORTh Carolina: Buncombe County, roadside near Black Mountain, Standley and Bollman IO3OI (Hb. U.S. 689122). Florida: Lake City, anonymus (Hb. Fla. Agricult. Coll. no. I279 in Hb. Field 234909); Key West, sandy places near the beach, J. K. Small 3720 (Hb. N. Y.; important as matching precisely Greenman's no. 47, topotype of X. chinense from vicinity of Vera Cruz). Ontario: Russell, near Nation River, July 28, I9II, John Macoun (Hb. Mo. 7I9899). Michigan: near Port Huron, roadside ditches, C. K. Dodge 43 (Hb. Gray); near Port Huron, roadside ditches, idem 45 (Hb. Gray); near Port Huron, marshes, idem 48 (Hb. Gray). KeNтuску: Bowling Green, Aug., I899, Sadie F. Price (Hb. Mo. 4600I).

1 For lack of space many specimens examined must be omitted here. Our citations are complete, however, as to the material examined from Mexico and the West Indies. 
Tennessee: vicin. Smyrna, Sept. 7, I898, H. Eggert (Hb. Mo. 85404 and 85405). West Virginia: Sweetsprings, Steele and Steele 271 (Hb. Gray; Hb. Mo. 8540r). Alabama: Auburn, in cultivated fields, F. S. Earle 2202 (2 sheets in Hb. N. Y.); Auburn, Sept. 18, I897, Earle and Baker (Hb. N. Y.). IlıINoIs: St. Clair County, Indian Lake, Sept. 25, r903, H. Eggert (Hb. Mo. 85420); Missourr: Swan, B. F. Bush 589 (Hb. Mo. 854II); Courtney, in fields, idem 87I (Hb. Mo. 85407); Courtney, in bottoms, idem 873 (Hb. Mo. 854Io); Courtney, in bottoms, idem 7809 (Hb. Mo. 809933); St. Louis, cultivated fields, especially in rich land, Aug. 1845, Dr. George Engelmann (Hb. Mo. 854I 5 and 85416); St. Louis, riverbanks, July, 1837, Carl A. Geyer (Hb. Mo. 854r4); Neck City, low ground, E. J. Palmer I304 (Hb. Mo. 8542I and 756630); Noel, Butler Creek, gravel bars, idem 4220 (Hb. Mo. 7I654I). Kansas: Atchison County, in fields, A. S. Hitchcock 727 (Hb. Gray; Hb. Mo. 85424); Riley County, low ground, J. B. Norton $26 I$ (Hb. Gray). Nebraska: Red Cloud, Rev. J. M. Bates 5450 (Hb. Gray). Oklahoma: Sapulpa, B. F. Bush 298 (Hb. Mo. 85426). Arkansas: Fulton, in fields, B. F. Bush 965 (Hb. Mo. 85422). Loursiana: Natchitoches, wet ground, E. J. Palmer 8727 (Hb. Mo. 79456r): Texas: Columbia, in fields, B. F. Bush 1348 (Hb. Mo. 85428); Dallas, in fields, J. Reverchon 259 I (Hb. Mo. 8543I; Hb. N. Y.). California: Fort Yuma, Colorado River bottoms, S. B. Parish 8360 (Hb. Gray;- a puzzling specimen, in some respects strongly suggesting $X$. strumarium $L$., which has been collected west of here by Brandegee at Cameron Lake. See X. strumarium L.). Mexico: La Laguna, near Vera Cruz, J. M. Greenman 47 (Hb. Field I89512; Hb. Gray). Bermuda IsLs.: Devonshire, cultivated ground, Brown and Britton 374 (Hb. Field 20389o; Hb. Gray); waste grounds near Tucker's Town, iidem I 724, (Hb. U. S. 758285). BAHAMA IsLs.: Nassau, waste grounds, Britton and Brace 383 (Hb. Field I7 I 8 I 5); Nassau, Nov., r89o, A.S. Hitchcock (Hb. Field r74738). CuBA: Playa de Cojimar, on coral limestone near the sea, Mar. 16-26, I906, A. S. Hitchcock (Hb. Field 235055); Prov. Havana, Santiago, plantations,

1 In the same herbarium (No.75900r) is another good specimen, by Eggert, from waste places, vicinity of East St. Louis, Illinois, Oct. 14, 1886; on the same sheet with it is a specimen, closely similar in habit and foliage, but in fruits approaching $X$. pennsylvanicum Wallr. with which species it seems to be a hybrid. This second specimen is identical with two others of the same date, by Eggert (Hb. Mo.721197; $\mathrm{Hb}$. Gray). A fifth specimen of the same date and locality, likewise by Eggert (Hb. Mo. 85526) is even more clearly a hybrid: its burs are fusiform, dark reddishbrown, sparsely and inconspicuously glandular-pubescent, very sparsely aculeate, with only about 25-40 uncinate, subglabrous (unless sparsely hispid at the base) prickles, the body of the mature burs about $1.6 \mathrm{~cm}$. long and $5.5 \mathrm{~mm}$. thick; prickles and beaks $4-6 \mathrm{~mm}$. long; the achenes mostly abortive. The burs of this last specimen present in their technical characters a slight resemblance to those of $\mathrm{X}$. Wootoni Cockll. but this resemblance is very superficial and disappears upon visual comparison of the two sorts. 
H. A. Van Hermann 360 (Hb. Field I72254); without locality, in I865, C. Wright (Hb. Gray). Santo Domingo: Sanchez, Rose, Fitch and Russell $435 \mathrm{I}$ (Hb. U. S. 760483). PoRTo Rico: Vieques Isl., Resolucion to Punta Arenas, in sand, J. A. Shafer 2901 (Hb. U. S. 790346). St. CRorx: Alfred E. Ricksecker 266 (Hb. Field 70621). TortolA: Sea-cow Bay, roadside, Britton and Shafer 928 (Hb. U. S. 756709). GUAdELOUPE: Pére Duss 2816 (Hb. Field 202726).

Apparently no other species of Xanthium has offered heretofore so baffling a problem concerning its true status as has this species. It has been referred at various times to such species as X. strumarium L., $X$. canadense Mill.,X.americanum Walt. etc. FromX. strumariumL. it differs as a rule very distinctly in having the burs larger, smoother and greenishbrown to reddish in color, not mostly yellowish-green; furthermore, the beaks in $\mathrm{X}$. chinense are longer. $X$. canadense, as we indicate elsewhere (p. 26 , foot-note) ${ }^{1}$ was merely X. orientale L., a species not known authentically in America and differing from $\mathrm{X}$. chinense in having stouter, more coarsely hooked and more hispid prickles and more arcuate beaks.

In I 768, Philip Miller (Gard. Dict. Edit. VIII, no. 4) advanced a new species of Xanthium which he termed $X$. chinense. He described the species briefly, " 4 . Xanthium (chinense) caule inermi ramosa, actleis fructibus erectis longissimis. China. Xanthium with an unarmed branching stalk, and the spines of the fruit very long and upright." He stated, in addition, that it grew "naturally in China from whence he had received the seeds." But, on inspecting his description, we find it to portray a species which no accounts show ever to have been collected in China, or anywhere else in the Eastern Hemisphere. The nearest approach to the description, as concerns the Orient, would be $\mathrm{X}$. strumarium L. However, not even the Egyptian form ${ }^{2}$ of $\mathrm{X}$. strumarium, the form with spines longer than usual $(2.5-3 \mathrm{~mm}$.), has spines so long as to explain or justify Miller's use of the word "longissimis." It is very likely that this seemingly insurmountable discrepancy between description and cited habitat has, in the past, entirely deterred botanists

${ }^{1}$ We have already stated (Field Mus. Bot. 4:2. I9I8) that the name canadense, advanced by Miller in the eighth edition of his Gardener's Dictionary, was equated in the ninth (posthumous) edition with X. orientale L. We may note, further, that Miller originally cited as a synonym of his species the diagnosis of $\mathrm{X}$. orientale $\mathrm{L}$. and gave also "X. majus canadense H. L. 635" " $C f$. Thellung; Verhandl. Bot. Verein Brandenb. 50": 139. 1908). But Thellung (loc. cit. I38) states in detail and, to us very convincingly, the evidence that this "X. majus canadense H. L. 635 " is merely the $\mathrm{X}$. orientale of Linnaeus. In fact, Linnaeus himself (Sp. P1. Edit. II: I400. 1763 ) cited "Xanthium majus canadense. Herm. lugdb. 635 " as the second synonym of his $\mathrm{X}$. orientale.

${ }^{2} X$. antiquorum Wallr., found also in Palestine. Cf. p.I7. 
from attacking the status of $\mathrm{X}$. chinense in a more than cursory way. ${ }^{1}$

Fortunately for our purpose, however, there appeared in I77I, the year of Philip Miller's death (fide Pritzel, Thesaurus 218. I872) and three years subsequent to the appearance of the eighth edition of The Gardener's Dictionary, an Abridgement of Miller's Gardener's Dictionary, sixth edition. ${ }^{2}$ In this abridgment, Miller introduced X. chinense from his Gardener's Dictionary, eighth edition, retaining the same peculiar description ${ }^{3}$ but omitting the word China. As we search his supplementary text, we find a most interesting statement: "The fourth sort [X. chinense] was discovered by the late Dr. Houston in the year I730, growing naturally at La Vera Cruz."

Now it happens that in I906, Dr. J. M. Greenman spent some time collecting in the neighborhood of Vera Cruz (Mexico) for Field Museum and, during the course of his work, collected specimens of Xanthium (Greenman 47) the fruits of which we find to match Miller's description strikingly. The prickles are not strongly inbent, as in the X. orientale L. that Miller knew, but erect ("erectis"). Nor are they short, as in the $\mathrm{X}$. strumarium L. known to Miller, but, by comparison, very long ("longissimis").

It appears to us to be beyond all doubt that Miller had made the acquaintance of this species in the prime of his life, during the period of his greater literary activity, but had not published it; - that late in life when seventy-seven years of age (fide Pritzel, Thesaurus 218. I872), he published an accurate though short Latin description under the name $X$. chinense, thinking that to it belonged various Chinese specimens sent to him;- - and that finally, just before his death, he realized his mistake in having referred Chinese specimens to the species and so, with a view to clarity, actually stated that the original specimens came from Vera Cruz.

An examination of the Greenman plants, which we may well take as representing $X$. chinense, shows them to be the same species that grows very commonly throughout the West Indies and which Bertoloni

1 Wallroth (Beitr. Bot. IIr: 223. I844) equated X. chinense with his $X$. discolor, which was a segregate from X. strumarium L. But Wallroth expressly stated for his $X$. discolor that the prickles were short ("kurz und abstehend eingebogene Stacheln"), whence it appears that he entirely ignored the character "longissimis" given by Miller.

2 Regarding the extreme rarity of this work, see Thellung (Verhandl. Bot. Verein Brandenb. 50 $0^{\text {II }}$ 144: 1908). We have been fortunate in securing excellent copies of the pertinent portions from the volume in the Library of the Arnold Arboretum, handwritten for us by the Librarian, Miss Ethelyn M. Tucker.

${ }^{3}$ Miller dropped the word ramosa after caule inermi and added the word simplicibus after erectis. 
described from Santo Domingo in 1822 , under the name X. occidentale. ${ }^{1}$ Moreover it is the same which Wallroth, in 1844 , named somewhat provisionally $X$. longirostre. Wallroth very clearly voiced his hesitancy in publishing a new name, but he had not seen authentic Santo Domingo specimens of $X$.occidentale with which to match his $X$. longirostre material from St. Thomas and Haiti, so was constrained not to equate the two names.

Specimens from the West Indies vary considerably in size of bur and in curvature and length of beaks. Sometimes the prickles are slightly short-hispid near the base,- not "simple" as described by Miller. The Greenman plants exhibit this same small departure from the original description. Commonly the burs are rather few, large, in color greenish-brown. A character frequently observed, especially in the West Indian material, is the peculiar appearance of many of the burs, their beaks being long, not widely divergent, somewhat incurved and suggesting the bill of a bird; this character is present on several burs of the Greenman plants.

Specimens from continental North America usually have the burs more numerous, smaller and more or less reddish in color. These specimens harmonize very well with the description of $X$. pungens Wallr., but the intergradations between the continental and West Indian forms are so numerous as to render vain all our attempts at separation." Hence we are compelled to regard $X$. pungens as merely a form or variety of X. chinense.

In not a few cases, $X$. chinense appears from herbarium specimens, to have formed hybrids with X. pennsylvanicum ( $c f$. p. 19, foot-note). At other times the fruits, varying to a coarse, more elongate, more hispid type, display a very close approach to those of the same species, but without suggestion of hybridity. On the whole, however, the two species are very easily distinguishable. ${ }^{3}$

${ }^{1}$ Raised from seed sent by Bertero from Santo Domingo. "Nux oblonga, medio ventricosa, utrinque attenuata, muricata, aculeis raris, subulatis, uncinatis, gracilibus, apice bi-trirostris, rostris convergentibus, viridis, vix puberula." (Bertol. Lucubr. Herb. 38 . I822).

' Rydberg (Dr. Per Axel), also Wiegand (Dr. Karl M.) each of whom made a somewhat extended preliminary study of the genus Xanthium and then postponed or abandoned the investigation, appear to have met with the same result. Thus we note on a sheet of typical West Indian material in Gray Herbarium (Brown and Britton 374, Bermuda) the annotation in pencil by Rydberg, " $X$. americanum P. A. R." and, by Wiegand, " $X$. pungens Wallr. K. M. W." By $X$. americanum, Rydberg meant, as his other herbarium annotations show, the $X$. pungens of Wallroth, which had of late been referred (by Britton and Brown, Illustr. Fl. Edit. II. 3: $346, f .4139$ ) to the enigmatic $X$. americanum Walt.

Thellung (Verhandl. Bot. Verein Brandenb. 50" I44. I908) equates X. pennsylvanicum Wallr., $X$. occidentale Bertol. and various other names categorically with X. echinatum Murr. The chinense of Miller he resolves into two parts, regarding the first or supposedly Chinese form as a variety of $\mathrm{X}$. strumarium L. and referring 
4. Xanthium Cylindricum Millspaugh and Sherff, Field Mus. Bot. $4: 4$, P1. 3. r9I8.

Caulis scabridus, verisimiliter $0.5^{-\mathrm{r} .5} \mathrm{~m}$. altus. Folia magna, quibusdam foliis Hibisci militaris Cav. simillima, subdeltoideo-ovata, trilobata (et fere hastata) aut quinquelobata, margine dentata, basi cordata aut subtruncata, membranacea, scabra aut tactui etiam fere levia, setulis adpressis minutis vestita, petiolis adjectis $\mathrm{I} .3-2.5 \mathrm{dm}$. longa, petiolis laminis subaequantibus. Fructuum (P1. VII., f. 4; Pl. VIII., ff. I6-20) corpus cylindrico-fusiforme, rubro-badium, glandulis minutis punctatum, aliter glabrum, $r .4-1.6 \mathrm{~cm}$. longum et $4-5 \mathrm{~mm}$. crassum; rostris arcuatis, ad apicem hamosis, glabratis, 4-5 $\mathrm{mm}$. longis; aculeis tenuibus, rubro-badiis, ad apicem hamosis, glabratis, $2.5-3.5 \mathrm{~mm}$. longis.

Distribution: North Carolina.

Specimens examined: North Carolina: Chimney Rock to Hendersonville, Oct. 3, I9or, J. K. Small and A. M. Huger (Hb. Field 40r3r 2, type; Hb. N. Y., cotype).

When this species was originally described, there was no question with us as to the soundness of the policy pursued by certain authors of regarding West Indian and United States specimens of $\mathrm{X}$. chinense as specifically distinct. But since then, our studies have convinced us, as stated under $\mathrm{X}$. chinense, that the United States specimens formerly referred to $X$. americanum (Auct. amer., forsan non Walt.; $X$. strumarium Auct. amer. ex parte, non L.; $X$. pungens Wallr.) represent merely an inconstant race or variety of the West Indian and Mexican $\mathrm{X}$. chinense. This being true, there arises the question as to whether $\mathrm{X}$. cylindricum likewise may not indeed prove to be a race of $\mathrm{X}$. chinense. So far, however, we have been unable to find intermediate specimens that seemed to connect adequately with $\mathrm{X}$. chinense. ${ }^{1}$ Hence we are constrained to reserve judgment in the matter until future studies shall have thrown more light upon the true status of this form.

5. Xanthium globosum Shull sp. nov. (Cf. Dalbey, Kansas Univ. Science Bull. 9: 57. r914; Shull, Bot. Gaz. 59: 474-483. r9r5.)

Caulis rubro-purpureus aut stramineus, saepe longitudinaliter purpureo-punctatus, 3 -ro dm. altus; ramis demum (in speciminibus robus-

the second or Mexican form to X. echinatum Murr. Clearly, Thellung was totally lacking as to a proper conception of $X$. occidentale ( $=X$. chinense), a species that, under various names, has become uniformly recognized in recent decades by prominent American authors as a valid species. Furthermore, even were Thellung's treatment correct and the first $\mathrm{X}$. chinense (published in 1768 ) reduced to synonomy with $X$. strumarium L., then the second $X$. chinense (published in $\mathrm{r} 77 \mathrm{r}$ ), based according to Thellung upon a different plant and being according to Thellung an entirely different species, would become valid and would take precedence over the name X. echinatum Murr. which Thellung maintains ( $C f$. Internat. Rules Bot. Nomencl. art. 50. 1906).

1 We have found two specimens of $X$. chinense from Missouri (Webber, roadsides, West St. Louis, Oct. I4, 1890, Hb. Mo. 46000 and 85413) that show small leaves suggestive in form and color of the larger ones on $\mathrm{X}$. cylindricum. 
tis) plus minusve elongatis, imis etiam r.I $\mathrm{m}$. longis. Folia non perspicue crassa, subdeltoidea, tri-aut quinquelobata et basi cordata, serrata, utrinque setulis adpressis scabra, petiolis adjectis $0.7^{-2.3} \mathrm{dm}$. longa, petiolis laminis subaequantibus. Fructus (P1. VII., f. 5; P1. VIII., ff. $2 \mathrm{I}-23$ ) saepe numerosi (circum I850 in uno specimine observatis, ex littera Shullii); corpore late ovoideo aut subgloboso, vix pubescenti sed glandulis minutissimis numerosis vestito, $0.9-1$. I cm. longo et $4.5-7 \mathrm{~mm}$. crasso; rostris rectis aut non rariter arcuatis, 3-4 mm. longis; aculeis levibus et rectis sed ad apicem hamosis, rostris subaequantibus.

Distribution: Missouri and Kansas.

SPECIMENS EXAMINED: Missouri: Randolph, "a very common weed," Kenneth K. Mackenzie 387 (Hb. Mo. 85408); Jasper County, La Russel, in waste places along railroads and in fields, Ernest J. Palmer I30I (Hb. Mo. 46004 and 756629). KANSAS: Lawrence, breeding grounds of Univ. of Kansas, Sept., I9I3, from original plants obtained on northern edge of Wakarusa flood plain about $0.5 \mathrm{~km}$. south of Mount Oread, Charles A. Shull (type in Hb. Field 477325); Lawrence, breeding grounds of Univ. of Kansas, Sept., I9I7, idem (Hb. Field 477328; lineal descendant from type material); Lawrence, in I9I7, idem (Hb. Field 477326; burs from typical plant growing wild); Lawrence, breeding grounds of Univ. of Kansas, in I9I 7 , idem (Hb. Field 477327; burs from lineal descendants of type material).

In I9I 5, Shull (loc. cit.), writing upon the physiological isolation of types in Xanthium, described this species. Unfortunately, however, no Latin diagnosis was published (as required by Article 36 of the International Rules of Nomenclature, adopted at Vienna in 1905), and so the name $X$. globosum must be regarded as having been heretofore unbinding and based upon a foundation very insecure. Early in I9I8 we took the liberty of writing to Dr. Shull regarding the proper publication of a complete taxonomic description in Latin. Dr. Shull promptly replied in a most cordial manner and very generously placed at our disposal, for publication, not only descriptive notes and photographs, but a sheet of the original type material, also other sheets bearing lineal descendants of the type material etc. We have thought it best to draw up our description rather closely from these sheets, hence a somewhat narrower description has been presented than would have been the case had we included the variations observed in the Missouri specimens.

A study of Shull's several specimens shows a high degree of uniformity among the fruits. The species is probably nearest to $\mathrm{X}$. chinense Mill., with which it perhaps intergrades, or hydridizes at times if left to itself. We have seen specimens from Maryland and from Iowa (G. H. Shull 392, along shore of Chesapeake Bay, south of Havre de 
Grace, Maryland, 2 sheets in Hb. Gray; Hb. Mo. 85399; A. S. Hitchcock, Iowa City, Iowa, without date, Hb. Mo. 85406) which, while referable to $\mathrm{X}$. chinense, showed a strong approach, in the subglobose character of the fruits, to $\mathrm{X}$. globosum.

6. Xanthium arcuatum Millspaugh and Sherff, Field Mus. Bot. 4: 4 . P1. 2. I9I8.

Caulis superne scabridus, $3-5 \mathrm{dm}$. altus. Folia deltoideo-ovata 3-5-lobata, dentata, basi cordata aut subtruncata, utrinque setulis adpressis scabra, petiolis adjectis circ. I dm. longa, petiolis laminis subaequantibus. Fructuum (P1. VII., f. 6; P1. VIII., ff. 24-26) corpus anguste ovatum, aculeis numerosis armatum, glandulis multis vestitum, demum I.3-I.5 cm. longum et 5-6 $\mathrm{mm}$. crassum; rostris rectis aut minime arcuatis, apice hamosis, non pubescentibus sed infra glandulos ferentibus, $3.5^{-5} \mathrm{~mm}$. longis; aculeis tenuibus, maximam partem arcuatis, plus minusve rubro-purpureo tinctis, apice hamosis, infra glandulosis, 4-6 $\mathrm{mm}$. longis.

Distribution: New York.

Specimens examined: New York: Chemung County, river shores and low places, Oct. I I, I896, T. F. Lucy (Hb. Field 4953, type).

A species with burs intermediate between those of $X$. chinense and those of X. pennsylvanicum, but having prickles more arcuate. Our failure to find, in various herbaria, additional material matching the type would seem to indicate that either $X$. arcuatum is a very rare species or that it will subsequently prove to be of hybrid origin.

\section{Xanthium curvescens sp. nov. PI. XI.}

Caulis ramosus, rubens, scaber, $\mp_{3} \mathrm{dm}$. altus. Folia deltoideocordata, infirme trilobata, margine dentata, scabrida, minute reticulata, punctis glandulosis numerosis minimis punctata, setulis minutis adpressis scabra, non crassa, petiolis adjectis $\mp \mathrm{I} \mathrm{dm}$. longa, petiolis laminas subaequantibus. Fructuum (Pl. VII., f. 7; Pl. VIII., ff. 27-29) corpus anguste cylindrico-fusiforme, rubro-badium, superne sensim angustatum et in duo rostra distantia productum, exteriore facie 30-50 aculeis armatum, glabratum sed glandulis minutis numerosis punctatum uti bases aculeorum et rostrorum; rostris et aculeis rectis solum inferne, superne valde arcuato-uncinatis; rostris crassioribus et passim paulo longioribus, inferne breviter hispidis; fructus corpore demum I.3-I.6 $\mathrm{cm}$. longo et $3.5-5 \mathrm{~mm}$. crasso; aculeis $3^{-6} \mathrm{~mm}$., maximam partem 4.5-5.5 $\mathrm{mm}$. longis.

Distribution: Vermont.

Specimens examined: Vermont: Orwell, Willard W. Eggleston I420 (type in Hb. Gray).

Because of its strongly bent prickles and beaks, we were disposed at first to regard this species as a form of the European X. orientale L. $\mathrm{But}$ in the many fruiting specimens of $\mathrm{X}$. orientale examined from 
Europe, we have found the fruiting involucres to be not only considerably larger, but brownish rather than reddish, also much more pubescent and the prickles nearly always more numerous. In its narrow, reddish, remotely aculeate fruits, this species suggests the next, $\mathrm{X}$. leptocarpum, the type of which was collected likewise in western Vermont, about three years earlier. Indeed, as a species, it seems to lie just half-way between $\mathrm{X}$. orientale and X. leptocarpum, and for a time we suspected it of being a hybrid between these two species. But the apparent absence of true X. orientale from all of North America ${ }^{1}$ would seem to

${ }^{1} \mathrm{X}$. orientale L. Sp. P1. Edit. II, 2: 1400 (ex descript. et synon.; excl. loc.) 1763; L. fil. Dec. II, P1. Rar. Hort. Upsal. tab. 17. 1763; Gaertner, Fruct. et Sem. P1. 2: tab. 164, f. 2. I791; O. Hoffmann, Engler and Prantl Natürl. Pflanzenfamilien $4^{\mathrm{v}}$ : 223, f. 112. 1889; X. elatius \& majus Americanum etc., Morison P1. Hist. Univ. Oxon. 604, sect. I5, tab. 2, f. 2 . I699; X. majus canadense Hermann, Hort. Lugd.Batav. 635. 1687 ( fide Thellung); Lappa canadensis minori etc., Ray, Hist. P1. I: I65. I686 (fide Thellung); X. canadense Miller, Gard. Dict. Edit. VIII, no. 2. 1768 (cf. Thellung, Verhandl. Bot. Verein Brandenb. 50": 138. I908; O. Hoffmann, Engler and Prantl. Natürl. Pflanzenfamilien $4^{\nabla}$ : 223. I 889 ); X. cuneatum Moench, Meth. Suppl. 300. 1802 (Moench gave an entirely inadequate description, "Xanthium, cuneatum, foliis cuneiformibus subtrilobis." He cited, however, "Xanthium orientale Linnaei" and "Xanthium majus Americanum fructu spinulis aduncis armato. Morison hist. III. p. 604, icon. Sect. 15 t. 2. f. 2 " for his two synonyms); $X$. echinatum Wallroth, Monogr. Xanthium in Beitr. Bot. III: 239. 1844 (Walpers Repert. Bot. Syst. 6: 152. 1846) non Murray; X. macrocarpum DC., F1. Franc. Suppl. 356. 1815 .

At various times in the past, Xanthium orientale L. has been reported as occurring in America. Thus, as late as 1913, Britton and Brown (Illustr. FI. Edit. II, 3: 346) stated that this species was "naturalized in the West Indies." But an examination of various specimens of Xanthium from the West Indies (among them a number from the Herbarium of the New York Botanical Garden, and determined as X. orientale L., evidently by Dr. Britton himself), fails to reveal to us a single specimen of $X$. orientale. Indeed, all so-called specimens of $\mathrm{X}$. orientale from the West Indies that we have seen are referable to $X$. chinense Miller and differ very markedly from X. orientale L.

Great confusion has existed heretofore among many botanists as regards the application of the name X. orientale. Linnaeus himself prefaced his original description with three synonyms ("Xanthium elatius majus americanum, fructu spinulis aduncis munito. Moris. hist. 3. p. 604. s. 15. t. 2. f. 2. Xanthium majus canadense. Herm. lugdb. 635. Lappa canadensis minori congener sed procerior. Raj. hist. 165") and with the statement, "Habitat in China, Japonia, Zeylonia."

If, on the one hand, we consistently follow the custom of taking earliest cited synonyms with which to establish our concept of the species, there can arise practically no doubt. To be sure, Morison's figure has most of the prickles drawn arcuate or even doubly bent, as in European plants of X. macrocarpum DC., while his American material must surely have been another species (the Jamaica plants, for example, undoubtedly belonging to X. chinense Miller). However, Morison definitely cited the Lappa Canadensis........ material of the Royal Garden of Paris as a basis for his species ("2. Elatius \& majus Americanum, fructu spinulis aduncis armato. Lappa Canadensis minori congener sed procerior, Hort. Reg. Par. E Virginia, Carolina \& Jamaicensi Insula accepimus. V. icon., tab. aen. 2."). And ( $c f$. Thellung, Verhandl. Bot. Verein Brandenb. $5^{\circ \text { it: }}$ 138. 1908) this cited material of the Paris Garden was X. macrocarpum DC.; for in the very year following the publication of Morison's work, Tournefort (Instit. I: 439; 3: tab. 252, f. M. I700) cited and illustrated this "Lappa canadensis........" material and his illustration is positively of the $X$. macrocarpum DC. Thus, by taking in turn the earliest cited synonym given by Linnaeus and by Morison, we find $\mathrm{X}$. orientale $\mathrm{L}$. to be the plant later named $X$. macrocarpum DC. Thellung (loc. cit.) has come to the same conclusion and he cites, furthermore, very strong evidence to show that the synonyms of Hermann and Ray likewise belong with the true $X$. macrocarpum DC., i.e., DC. F1. Franc., loc. cit. Later, De Candolle (Prodr. 5: 523. 1836) unfortunately 
make an assumption to this effect purely gratuitous. Nor do we feel inclined to regard our plant as an anomalous race or variety of $\mathrm{X}$. leptocarpum, since the arcuate character of its prickles is a character that holds with a high degree of uniformity throughout the specimens of the corresponding X. orientale of Europe. ${ }^{1}$

admitted other, specifically different material to his $X$. macrocarpum and so it is highly important that, for a correct concept of the species, recourse be had only to his original treatment in the Flore Francaise. The true $X$. macrocarpum $D C$. is a plant with strongly hooked beaks and the prickles somewhat subremote, stoutish, tending to be not only hooked at the apex, but also arcuate, often backwardly then forwardly, from about the middle upward.

On the other hand, there is good reason for discarding the Linnaean synonyms entirely, since Linnaeus himself advanced them in an interrogative way. Thus, at the close of his description, he asked the question, "Synonyma americanae plantae an differant?" Clearly, Linnaeus did not establish his species upon certain synonyms and then doubtfully refer the plant under observation to it; but he did base his species upon the plant material studied, drawing up a (for that period) good description of it, and then to this species the interrogative mark and the wording of the question show that he doubtfully referred the early synonyms. (This point is indeed important, for in case a discrepancy did exist between the synonyms and the plant of the description, it is evident that Linnaeus definitely advanced the description and not the synonomy. But, fortunately, no such discrepancy appears to have existed.) - Linnaeus' doubts were evidently inspired by the fact that the cited references, although agreeing with his plant, all had been regarded as pertaining to American material. If we note his own citation of habitat, we find that he regarded his Xanthium orientale as belonging to China, Japan and Ceylon. But, it happens that his description is illuminated by a good, clear illustration published the same year (1763) by his son, from plants at the Garden of Upsala. This illustration is very decisive. It shows the Linnaean plant material of $\mathrm{X}$. orientale to have been $a$ European plant (X. macrocarpum DC.), a plant that we have never known to come from the Orient.

In I8I5, De Candolle (loc. cit.) created the name Xanthium macrocarpum as a straight synonym for the Linnaean description of Xanthium orientale and for the illustration by Iinnaeus' son. He was impelled to create the new name X. macrocarpum because the species had not been proved to grow in the Orient and because, even if it had, the name orientale would be hardly appropriate, since the plant had been collected in Languedoc: "La description de Linné, la description et la figure de Linné fils se rapportent parfaitement à notre plante; malgré cela j'ai cru convenable de ne pas lui conserver le nom d'orientale, $\mathbf{I}^{\circ}$. parce qu'il n'est pas prouvé que cette plante croisse en Chine, au Japon, à Ceylan; $2^{\circ}$. parce que cette habitation supposée certaine, le nom d'orientale ne serait guère convenable, l'espèce se trouvant en Languedoc. $\odot$ Elle a étté trouvée dans les vignes du bas Languedoc, par mademoiselle Lucie Dunal." (Among various authentic French specimens of this species we have seen an old one from De Candolle himself, collected in this same region, at Montpelier. It is in the Torrey Herbarium, now at the Herbarium of the New York Botanical Garden.)

De Candolle's procedure in seeking to supplant the name $\mathrm{X}$. orientale with the name $X$. macrocarpum would not, of course, be sanctioned by the Vienna Code (Internat. Rules Bot. Nomencl., art. 50. I906), and clearly the name X. orientale L. must be retained.

Our search through botanical literature fails to show any true $\mathrm{X}$. orientale to have been collected in North America during recent times ( $C f$. Thellung. loc. cit. I4I : "Indessen ist das echte $X$. orientale aus Nord-Amerika, wenigstens in neurerer Zeit, nicht mit Sicherheit bekannt geworden.")

1 On the eve of publication, we have received an admirable set of specimens collected for us by Mrs. Nellie F. Flynn at Burlington, Vermont. The set includes Xanthium chinense, X. speciosum, X. italicum, X. leptocarpum and X. curvescens. We have deposited the material of $X$. curvescens in $\mathrm{Hb}$. Field, nos. 481623, 481624, $481625,481626,481627,481630 ; \mathrm{Hb}$. Gray; Hb. N. Y. Its burs show a curious simulation of those of $X$. orientale L., but are much smaller. It was found growing with $X$. italicum and $\mathrm{X}$. leptocarpum. This fact naturally leads to the inquiry as to whether or not $\mathrm{X}$. curvescens may ultimately prove to be of hybrid origin. 
8. Xanthium Leptocarpum Millspaugh and Sherff, Field Mus. Bot. 4: 3, Pl. I. IgI8.

Caulis superne scaber, $3-5 \mathrm{dm}$. altus. Folia plus minusve deltoidea et trilobata, dentata, basi cordata aut subtruncata, utrinque setulis adpressis scabrida, petiolis adjectis $7-\mathrm{I} 9 \mathrm{~cm}$. longa, petiolis laminis subaequantibus. Fructuum (P1. VII, f. 8; P1. VIII, ff. 30-32) corpus anguste cylindrico-fusiforme, badium, superne sensim angustatum; exteriore facie et basibus aculeorum et rostrorum pubescentibus, glandulosis; $18-40$ aculeis remotis, $2-3$ aut rare $-4 \mathrm{~mm}$. longis; rostris distantibus, arcuatis; rostris et aculeis ad apicem hamosis, rostris crassioribus et paulo longioribus; fructus corpore $1.3-1.6 \mathrm{~cm}$. longo, 3.5-5 $\mathrm{mm}$. crasso.

Distribution: Vermont.

Specimens examined: Vermont: Burlington, Sept. I2, I896, L. R. Jones ( $\mathrm{Hb}$. Field 430860, type); Shores of Lake Champlain, Oct. 30, 1895, and Sept. 8, 1806, Ezra Brainerd (Hb. Gray).

This species appears most closely allied with $\mathrm{X}$. Wootoni Cockll. Careful comparisons, however, of the type and supplementary material with authentic specimens (cited below) of $\mathrm{X}$. Wootoni do not permit us to equate the two species. The burs of $\mathrm{X}$. leptocarpum are uniformly much narrower; moreover, they have about twice as many prickles as do those of $\mathrm{X}$. Wootoni and their beaks show no tendency to be more or less cleft. ${ }^{1}$

9. Xanthium Wootoni Cockerell ex De Vries, Sp. and Var. I40. I905; cf. Proc. Biol. Soc. Wash. I6: 187. I903.

$X$. commune var. Wootoni Cockerell, ibid., p. 9. 1903.

$X$. Wootoni Auct. ex Index Kew. Suppl. 3: I9I. I908.

$X$. oligacanthum Piper, Contrib. U. S. Nat. Herb. II: 55 I. r $906 .^{3}$

Caulis erectus aut sese extendens, sparsim scabrido-hispidus, 3-6 dm. altus. Folia reniformi-orbiculata aut deltoideo-cordata, obscure lobata, crenato-dentata, setulis minutis adpressis scabrida, petiolis adjectis 0.8-r.5 dm. longa, petiolis laminas aequantibus aut paulo excedentibus. Fructuum (P1. VII, f. 9; P1. VIII, ff. 33-36) corpus oblongum, vel stramineum vel badium vel etiam rubro-fuscum, superne sensim angus-

1 See also footnote (p. 27) under X. curvescens.

${ }^{2}$ See also Science, New Series, 42: 87r. I9r5.

We have purposely given the synonomy as fully as we can. Cockerell originally proposed the plant as a variety. But, in accordance with their entirely unjustified method of indexing varieties, subspecies etc., as species, the Biological Society of Washington indexed the plant at the back of their volume as a species. In 1905, De Vries (loc. cit.) first stated the binomial at all creditably and he definitely attributed the name to Cockerell. As the retention of a multitude of taxonomic binomials, each accredited merely to some anonymous author (e.g., "Auct." in Index Kew." loc. cit.) can result only in endless confusion in the future, we feel ourselves in accord with the spirit of the Vienna Code (Internat. Rules Bot. Nomencl., art. 4: 2. I906) in taking De Vries' book as the place of valid publication. 
tatum et in duo (aut rarius tria) rostra distantia productum, I 2-30 aculeis $\left(3.5^{-6} \mathrm{~mm}\right.$. longis) armatum, molliter glanduloso-pubescens uti bases aculeorum et rostrorum, I.I-I.4 (rariter I.6) $\mathrm{cm}$. longum et 5-6 $(-7$, fide Piperi) $\mathrm{mm}$. crassum; rostris rectis aut versus apicem incurvatis, saepe hiantibus et achaenia in conspectu ponentibus, aculeos aequantibus; aculeis rectis aut subrectis sed ad apicem hamosis, non pubescentibus nisi versus basim.

Distributron: Massachusetts, New Mexico and Washington.

Specimens examined: Massachusetts: South Boston, made land, Oct. 4, I909, Walter Deane (2 sheets, Hb. Gray). New Mexico: Las Vegas, T.D. A. Cockerell I5 (author's material of X. commune Wootoni Cockerell, Hb. N. Y.); Las Vegas, in 1902, idem (author's material of $X$. commune Wootoni Cockerell, Hb. Gray). Washington: Waitsburg, bars of streams, Robt. M. Horner B. 272 (Hb. Gray); Bolles, in fields, Sept. I8, I893, C.V. Piper (Hb. N. Y.; cotype of X. oligacanthum Piper).

Repeated studies upon this species have indicated it to be distinct and worthy of specific rank. DeVries (loc. cit.) found that the seed sent him by Cockerell (who was the first to pay particular attention to the plant) produced, when planted in DeVries' garden, plants true to type. Wooton and Standley (Contrib. U. S. Nat. Herb. I9: 635. I9I5), while reluctantly retaining the form as a variety of Xanthium commune Britton (=X. italicum Moretti), state nevertheless that it "seems distinct enough from $X$. commune to be regarded as a species. It certainly is more easily separable from that than are most of the eastern species from each other. ... . . Ordinarily the two plants are distinct enough." Cockerell himself (Science, New Ser. 42: 87I. I915), although at first inclined to regard the plant as a variety, finally, as a result of an additional observation upon $X$. commune and also in view of DeVries' results, stated, "We must apparently conclude that $\mathrm{X}$. Wootoni is a valid species, but that commune from time to time varies or mutates to a virtually identical form." And, several years before, Piper regarded it as a species. He stated that it differed "from any other American species in the small size of the fruit and the relatively few prickles" (Piper, loc. cit.). But, as he was dealing with specimens from Washington, he apparently overlooked the literature dealing with $\mathrm{X}$. Wootoni, which had been known only from New Mexico; - hence the reason for his name $X$. oligacanthum.

We have studied several authentic specimens from New Mexico and from Washington. There is no essential difference to be found between the two sets of specimens. Those from Washington have burs more brownish in color (rather than whitish to straw-colored) and the prickles are very slightly stouter. But both have the beaks of the burs tending 
to be strongly cleft or 2 -valved (sometimes more or less malformed), ${ }^{1}$ and in various other characters are too close to admit of any taxonomic separation.

The specimens collected by Deane in Massachusetts have the numerous burs identical with those on Piper's plant from Washington, but the leaves differ noticeably in being sharply lobed and dentate. Our knowledge of the genus, however, convinces us that the foliage characters are entirely too unstable to warrant satisfactory segregation of forms when unaccompanied by definite characters of the fruits. Hence we must refer the Massachusetts plants to this species.

\section{Xanthium cenchroides, sp. nov.}

Caulis longitudinaliter plus minusve purpureo-maculatus, supra subscabridus. Folia non crassa, dentata, supra scabrida, infra scabra et minute reticulata. Fructus (P1. VII, f. Io; P1. VIII, ff. 37-39) ovati, superne in duo rostra producti; exteriore facie glanduloso-hispida et circum 25 aculeis armata; corpore (rostris non adjectis) $\mathrm{r} .5^{-\mathrm{I} .7} \mathrm{~cm}$. longo et 6-7 mm. lato; rostris arcuatis, infra hispidis, supra glabratis et ad apicem hamosis, circum $8 \mathrm{~mm}$. longis; aculeis rectis aut subrectis, infra hispidis, supra glabris et ad apicem hamosis, 8-1o $\mathrm{mm}$. longis.

Distribution: Texas.

Specimens examined: Texas: near Ferris, J. Reverchon 2332 (type in Hb. Mo. $855^{6} 3$; additional material, ibid., on sheet no. $855^{64}$ ).

The type material is very fragmentary, the leaves nearly all having been destroyed by worms. The fruiting burs, however, are present in fair quantity and are very distinct from those of any other Xanthium known to us. In their small number of prickles, the burs resemble those of X. Wootoni Cockll., but in size of body, length of prickles etc., there are very pronounced differences. The burs suggest very strongly the fruiting involucres of Cenchrus carolinianus Walt., although of course much larger.

I I. Xanthium inflexum Mack. and Bush, Rept. Missouri Bot. Gard. 16: 106. 1905.

Caulis glabratus aut superne setulis albis plus minusve scabridus, ramosus, I-I.5 m. altus. Folia cordata aut ovato-cordata, tri-aut subquinquelobata, irregulariter serrata aut dentata, infirme aut valide scabrida, petiolis adjectis $0.8-2.5 \mathrm{dm}$. longa, petiolis laminis subaequantibus. Fructuum (Pl. VII, f. Ir; Pl. IX, ff. I-4) corpus oblongo-ellipticum aut ovato-oblongum, exteriore facie non paucis aculeis armatum, aliter glabrum aut sparsim glandulosum, I.3-I.7 $(-2) \mathrm{cm}$. longum et 6-7.5 mm. crassum; rostris validis, maturis ad medium abrupte flexis, valde incurvatis, ad apicem hamosis, saepe mutuo contingentibus, infra

\footnotetext{
1 The specimen collected by Piper has several burs with the achenes protruding at the top.
} 
glanduloso-pubescentibus, plerumque $5-7 \mathrm{~mm}$. longis (auctores "circ. ro mm. longis" dixerunt inaccurate); aculeis tenuibus, subconfertis, plerumque arcuatis, ad apicem hamosis, infra glanduloso-pubescentibus aut demum glabratis, $4 \cdot 5^{-6.5} \mathrm{~mm}$. longis, saepe quibusdam abnormalibus versus rostra longissimis (8-10 $\mathrm{mm}$.).

Distribution: Southwestern Illinois to Arkansas.

Specimens examined: Massachusetts: Cambridge, Botanical Garden, Oct., I848, from seed collected by Engelmann (presumably collected the preceding year at East St. Louis, Illinois) Asa Gray (two sheets in Hb. Gray, bearing nos. $172,172 a$ and 174 ). IllinoIs: East St. Louis, river bank, Sept., I847, George Engelmann (Hb. Mo. 8555I); Missourr: Courtney, in bottoms, B. F. Bush 860 (Hb. Gray; Hb. Mo. 855I9; an atypic form apparently hybridized with $\mathrm{X}$. pennsylvanicum Wallr.); Courtney, in bottoms, idem I 804 and I805 (Hb. Mo. 85409 and 8553 I respectively); Courtney, in bottoms, idem I 806 (Hb. Mo. 85522; $\mathrm{Hb}$. Gray); Courtney, in bottoms, idem r $9 \mathrm{r} 6$ (Hb. Mo. 85520 and $8552 \mathrm{I}$; $\mathrm{Hb}$. Gray; - type material). ArKansas: Fulton, along river, $B . F$. Bush 1026 (Hb. Mo. 85554 and 85555; Hb. Gray;- a form approaching $\mathrm{X}$. pennsylvanicum Wallr., the burs having long, somewhat delicate beaks, which are not decidedly inflexed).

Fortunately, we have been able to examine fairly numerous specimens of this little known species. The burs have a body averaging of larger size than in X. chinense Mill.; in shape and appearance the body is intermediate between that in X. chinense Mill. and that in X. pennsylvanicum Wallr. The prickles are long, as in X. speciosum Kearney, but more slender, much smoother and somewhat less abundant.

I2. X. Pennsylvanicum Wallr. ${ }^{1}$ Beitr. Bot. $\mathrm{I}^{\mathrm{In}}$ : 236 . I844.; Britton and Brown Illustr. Fl.; Edit. II, 3: 346, f. 4I37. I9I3.

$X$. pennsylvanicum vars. glandulosum and eglandulosum Wallr. loc. cit.

$X$. saccharatum Wallr. loc. cit. 238 ;

$X$. affine Greene, Pittonia 4: 60.1899 .

$X$. californicum Greene and $X$. acutum Greene, loc. cit. 62.

Caulis subtenuis scabridus, aut infra levis, $3-9 \mathrm{dm}$. altus. Folia deltoideo-ovata aut cordata, dentata, saepe acute 3-5-lobata, utrinque setulis minutis adpressis scabra, petiolis adjectis $0.7-2 \mathrm{dm}$. longa, petiolis laminas subaequantibus aut excedentibus. Fructuum (P1. VII, f. I 2; PI. IX, ff. 5-10) corpus nunc anguste cylindricum, nunc oblongum, nunc ovato-fusiforme, nunc etiam ovoideum, sed plerumque plus minusve cylindricum, glabrum aut glabratum aut pilis glandulosis brevibus vestitum, $\mathrm{I}-2 \mathrm{~cm}$. longum et $5-8 \mathrm{~mm}$. crassum, aculeis armatum; rostris tenuibus aut crassis, infra glanduloso-pubescentibus, versus

1 The name as originally given by Wallroth was spelled $\mathrm{X}$. pensylvanicum. Fernald (Rhodora I9: 70. I917) is inclined to retain the old spelling in such cases and gives the historical reasons for pursuing such a course. 
apicem glabris et saepius incurvatis, ad apicem hamosis, 4-6 mm. longis; aculeis subremotis et subvalidis (aut rarius confertis et tenuibus), versus basim glandulosis et saepe sparsim pubescentibus, aliter glabris, ad apicem hamosis, interdum purpureo-tinctis, 3-7 $\mathrm{mm}$. longis.

Distribution: Massachusetts, Ontario and Washington to Florida, Texas and California; perhaps also in Mexico; frequent in the Hawaiian Islands.

Specimens examined (partial list): ${ }^{1}$ Massachusetts: Boston, Sept. I3, I895, Emile F. Williams (Hb. Gray). Rhode Island: Newport, waste ground, Fernald and Long 10658 (Hb. Gray). Pennsylvania: without locality, invading the marshes ("in paludos"), Sept., I824, Poeppig (Hb. Mo. 85594; cotype of $X$. pennsylvanicum var. eglandulosum Wallr.). Maryland: Plummer's Island, near Cabin John, $T . H$. Kearney $22 \mathrm{I}$ (Hb. U. S. 640384); east shore of Maxwell's Point, above tide, George H. Shull 332 (Hb. Gray); shore of Chesapeake Bay, south of Havre de Grace, idem 390 (Hb. Gray; Hb. Mo. 85436). Virginia: Alexandria County, near.Barcroft Station, Oct. 3, I9 5, E. S. Steele (Hb. U. S. 64328I). Florida: Hillsborough County, waste ground, A. Fredholm 6426 (Hb. Gray). Ontario: near Sarnia, roadside ditches, C. K. Dodge 49 (Hb. Gray). Michigan: Port Huron, dryish ground in streets, C. K. Dodge 47 (Hb. Gray). Illinois: near French Village, Sept. 6, I892, H. Eggert (Hb. Mo. 85438); East St. Louis, Sept., I847, Dr. George Engelmann (Hb. Mo. 85452); Carthage, F. C. Gates 9996 (Hb. Field 472736); vicin. of Catlin, bank of creek, O. E. Lansing, Jr., 3532 (Hb. Field 34659o); Urbana, open wet soil, Sept. I9, I9or, $M$. S. Sheldon (Hb. Gray); Chicago, along walk, Earl E. Sherff 3080 (Hb. Field 480737 and 480738); Hinsdale, waste ground, Ernest C. Smith 529, (Hb. Field г270r8). Kentucky: locality not stated, in I842, Dr. C. W. Short (Hb. Gray). Iowa: Decatur County, in fields, Aug. 29, I897, Fitzpatrick and Fitzpatrick (Hb. Gray); Ames, without date, A. S. Hitchcock (Hb. Mo. 85450). MissourI: Courtney, in bottoms, B. F. Bush 870 (Hb. Mo. 85539); Courtney, in bottoms, idem I789 (Hb. Gray); Courtney, in bottoms, idem I790 (Hb. Mo. 85538); Courtney, in bottoms, idem I792 (Hb. Mo. 85530); Courtney, in bottoms, idem I793 (Hb. Mo. 85542); Courtney, in bottoms, idem I794 (Hb. Mo. 85529); Courtney, in bottoms, idem I802 (Hb. Gray; Hb. Mo. 85602); Courtney, in bottoms, idem I809 (Hb. Mo. 8554I); Courtney, in bottoms, idem IOII and IgI4 (Hb. Mo. 85540 and 85533 respectively; probably hybridized with X. chinense Miller); Courtney, in bottoms, idem Igr 5 (Hb. Mo. 85537); St. Louis, Aug. 25, I874, H. Eggert (Hb. Gray); St. Louis County, West Webster, Dr. J. M. Greenman 3799 (Hb. Mo. 807756);

1 A large number of specimens omitted here from lack of space. 
Webb City, low ground, E. J. Palmer 767 (Hb. Mo. 7566 26); La Russell, low ground, idem 1300 ( $\mathrm{Hb}$. Mo. 85456; fruit with bristly prickles and approaching that of $\mathrm{X}$. italicum Mor.). ARKANSAS: Fulton, along river, B. F. Bush 1027 and 1028 ( $\mathrm{Hb}$. Mo. 85423 and 85543 respectively). North Dakota: Leeds, waste places, Aug. 21, 1902, Dr. J. Lunell (Hb.Gray). Nebraska: Red Cloud, Rev. J.M. Bates 4745 (Hb.Gray). Kansas: Manhattan, Sept. 20, 1887, W. A. Kellerman (Hb. Mo. 85449); Riley County, low ground, J. B. Norton $26 I$ (Hb. Mo. 85448). OKLAнома: Sapulpa, B.F. Bush 299 (Hb. Mo. 85544); vicin. Ottawa, low waste place, $G$. W. Stevens 2568 (Hb. Gray). Texas: Columbia, in sand, B. F. Bush I 344 (Hb. Mo. 85467); Dallas, in wastes, J. Reverchon 2589 (Hb. Mo. 85480, 8548x and 85546). Colorado: Naturita, moist ditch bank, Ernest P. Walker 545 (Hb. Gray; Hb. U. S. 544637). Nevada: Washoe County, Truckee Pass, Sept. I5, I909, A. A. Heller (Hb. Calif. r 96027 ; a form with burs precisely like those on type of $X$. acutum Greene at $\mathrm{Hb}$. Greene, except slightly pubescent). IdaHo: New Plymouth, waste ground, J. Francis Macbride 718 ( $\mathrm{Hb}$. Gray, having burs almost exactly identical with those on type of $X$. acutum Greene, in $\mathrm{Hb}$. Greene; a rather immature specimen is also in Hb. Mo. 85515). UтAн: Vermilion, Marcus E. Jones 5842 (Hb. Mo. 85490 and 85492); Peterson, Peterson Canyon, Pammel and Blackwood 3888 (two sheets in $\mathrm{Hb}$. Gray); road between Monticello and Bluffs, Rydberg and Garrett 9872 (Hb. U.S. 765345). Arizona: Tucson,Valley of Santa Cruz River, John J. Thornber 8 (Hb. Mo. 85496; Hb. Calif. I 29897). Washington: Waitsburg, bars of streams, Robt. M. Horner B 273 (Hb. Gray; this is not $X$. varians Greene as erroneously stated by Piper, Contrib. U. S. Nat. Hb. Ir: 55I. r906); West Klickitat County, sandy banks of Columbia River, W. N. Suksdorf 1584 (Hb. Field $8975^{2}$ and 89753; Hb. Calif. r30204; Hb. Gray; $\mathrm{Hb}$. Greene 19830; type and cotypes of $X$. affine Greene). Oregon: Union County, Snake River, sand-bars, W. C. Cusick Iooo (Hb. Gray); near Prineville, J. B. Leiberg 842 (Hb. Gray). California: Los Angeles County, near Soldiers' Home, Sept., I905, Dr. J. Q. Adams (Hb. Calif. 74043); San Diego County, vicin. Ramona, Stockton Ranch, Oct., r905, Katharine Brandegee (Hb. Calif. I6874I; burs identical with those on type and cotypes of $X$. affine Greene); vicin. Ramona, Stockton Ranch, Oct., 1905, eadem (Hb. Calif. 168816; a form with burs matching those on type of $X$. californicum Greene in Hb. Greene); vicin. Ramona, Stockton Ranch, Oct., eadem ( $\mathrm{Hb}$. Calif. r688r 3 ); vicin. Mendocino, H.E. Brown 938 (Hb. Mo. 8539r; this is not $\mathrm{X}$. echinatum Murr., as erroneously stated by Thellung, Verhandl. Bot. Verein Brandenb. 50": 144. I908); roadside near Yreka, George D. Butler 527 ( $\mathrm{Hb}$. Calif. r64I45); Escondido, Harley P. Chandler 5399 
(Hb. N. Y.); Temescal, Oct., I889, Edward L. Greene (Hb. Greene I9822; Greene's only specimen of his $X$. californicum and by us regarded as the type; matched most minutely by W. L. Jepson's plant from Oakland,- - see below); Amador County, Middle Fork, George Hansen 700 (Hb. Mo. 85389); Suisun Marsh, along railroad near Suisun, A. A. Heller 7550 (Hb. Gray; Hb. Mo. 85386; Hb. N. Y.); cultivated land, north of Oroville, idem 12647 (Hb. Field 460600 ; Hb. Mo. 802978; atypical and approaching X. italicum Mor.); Rio Vista, bank of Sacramento River, Sept. I6, I891, W. L. Jepson (Hb. Calif. 36799 ; this is a form intermediate between the types of $X$. acutum Greene and $X$. californicum Greene, in Hb. Greene); Oakland, Oct. I, I894, idem (Hb. Mo. 85387; the exact form described by Greene as $X$. californicum and important as coming from the range emphasized by him, "Middle California, especially about San Francisco Bay"); near San Francisco, in I866, Dr. A. Kellogg (Hb. Gray); near Stockton, in $\mathrm{I} 888$, J. A. Sanford (Hb. Greene I9819; type of $X$. acutum Greene).

Wallroth divided this species into two varieties, a. glandulosum and $\boldsymbol{\beta}$. eglandulosum, according to the presence or absence of minute glands upon the fruits and lower surfaces of the leaves. The var. glandulosum was collected by Beyrich at Asheville [North Carolina] in I833, while the var. eglandulosum was collected by Poeppig in Pennsylvania, Sept., I824. We have not seen type material of var. glandulosum; of var. eglandulosum, however, we have seen the cotype specimen in the Bernhardi Herbarium (Hb. Mo. 85594). But this shows clearly, under a lens with a magnification of fourteen diameters, many minute glands,- evidently missing on the type or perhaps overlooked by Wallroth. Thus Wallroth's separation of the species into two varieties is seen to be without real basis in fact.

Among botanists there has been almost endless confusion between $\mathrm{X}$. pennsylvanicum and the species treated below as true $\mathrm{X}$. italicum Mor. Our own experience in the herbarium indicates these to be, without question, distinct. In the field, our numerous observations during the season of $\mathrm{I} 9 \mathrm{I} 8$ show that, where the two grow side by side, $\mathrm{X}$. italicum commonly displays a more compact mass of burs near the apex of the stem and branches than does $\mathrm{X}$. pennsylvanicum. This compactness, added to the greater pubescence of the burs, often imparts to $\mathrm{X}$. italicum an appearance very unique.

Of $X$. saccharatum Wallr., there is the cotype in Gray Herbarium. This is plainly $X$. pennsylvanicum. We find a badly scrawled name given for the locality to say "Bexar." Clearly the plant (Berlandier 1865) was collected at Bexar, Texas, and not in Mexico as some writers have persisted in stating (although, to be sure, Texas had been a part 
of Mexico until shortly before Wallroth's publication of the name $X$. saccharatum). ${ }^{1}$

Of $X$. affine Greene, $X$. californicum Greene ${ }^{2}$ and $X$. acutum Greene, we have seen the types (all in $\mathrm{Hb}$. Greene); of $X$. affine we have seen also various cotypes. So different do these forms appear at first that one might well mistake them as typifying three distinct species. However, the large number of herbarium specimens that we have examined from the Pacific Coast show that specific segregation is entirely impossible. So polymorphous does $\mathrm{X}$. pennsylvanicum become in its western range that, in California alone, as many as six or seven forms may be found. In the eastern part of the United States, $X$. pennsylvanicum displays much less variation, both in fruits and in general habit.

\section{I3. Xanthium calvum sp. nov. P1. XII.}

Caulis erectus, rubescens, saepe maculis purpureis parvis longitudinalibus punctatus, subscabridus aut infra etiam glaber, circ. $4-9 \mathrm{dm}$. altus. Folia ovato-cordata aut ovato-triangulata, ad basim vel orbiculata vel truncata vel cordata, plerumque atro-viridiora, crenato-dentata, saepe dentato-lobata, setulis minutis adpressis scabrida, petiolis adjectis $0.6-2 \mathrm{dm}$. longis, petiolis laminis subaequantibus. Fructus (P1. VII, f. I3; Pl. IX, ff. II-I2) pauci aut numerosi, corpore crasso ovatofusiformi fusco, utrinque subacuto, exteriore facie breviter et minime pubescenti, glanduloso, aculeis subremotis armato, I.5-I.8 cm. longo, circum $8 \mathrm{~mm}$. crasso; rostris infra crassis et validis, ad basim glandulosopubescentibus, ad medium plerumque inflexis, ad apicem plus minusve hamosis, $3-5 \mathrm{~mm}$. longis; aculeis rectis, ad basim glandulosis aut rariter pubescentibus, aliter glabris, ad apicem hamosis, 4-6 $\mathrm{mm}$. longis; rostris et aculeis plerumque purpureo-tinctis, praesertim versus apicem.

Distribution: California.

Specimens examined: California: vicin. of Palo Alto, foothills, C. F. Baker I760 (Hb. Calif. I3 I 236, type; Hb. Field 22660I; Hb. Gray; Hb. Mo. 85385 ; Hb. N. Y.); Neponset, Salinas River, L. R. Abrams 4023 (Hb. Calif. I49r39); West Berkeley, Harriet A. Walker 478 (Hb. Calif. I3005I).

${ }^{1}$ It may be remarked that the type of $X$. crassifolium Millsp. and Sherff (Field Mus. Bot. 4:5.1918) was collected at San Antonio, not far from Bexar, in Bexar County, Texas. The two plants show a close resemblance, but the Berlandier plant is much thinner-leaved and less scabrous. We are disposed to consider $X$. crassifolium as probably a variety or race of $X$. pennsylvanicum, - a conclusion that we have reached also in the case of $X$. acutilobum Millsp. \& Sherff (loc. cit., p. 6). Since describing $X$.crassifolium (Field Mus. Bot. 4:4. I9I8) we have found several somewhat intermediate herbarium specimens. One of these, $C$. $L$. Shear 220, vicin. of Osborne City, Kansas, Aug. 27, I894 (Hb. Gray), has the coarse, highly scabrous stem and leaves of $X$. crassifolium, but the leaves are large, as in X. pennsylvanicum.

${ }^{2}$ At various times in later years, Dr. Greene erroneously determined certain specimens of Xanthium as representing his $X$. californicum. These belonged to $X$. pennsylvanicum, $X$. calvum, etc. Greene's own type specimen of $X$. californicum was, as stated above, the same form as that collected by W. L. Jepson, Oakland, California, Oct. I, 1894 ( $\mathrm{Hb}$. Mo. 85387), a form of X. pennsylvanicum. 
A species with very unique aspect of foliage as well as of fruit. Specimens of the type collection had been determined by E. L. Greene as $X$. californicum Greene ( $c f$. p. 35, footnote 2). But a study of Greene's type of $X$. californicum shows no approach in fruit characters to the type of $X$. calvum. We have seen several sheets of $X$. pennsylvanicum having fruits typical of that species but with foliage offering a perplexing

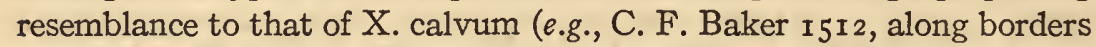
of marshes, Palo Alto, California, Hb. Gray; Harley P. Chandler 5399, Escondido, California, Hb. Calif. 64835). Future investigation upon the status of such forms, which are possibly hybrids, would seem highly desirable.

The specific designation calvum is given in allusion to the bald or smoothish appearance of the body and prickles of the mature fruit.

\section{Xanthium palustre Greene, Pittonia 4: 63. I899.}

Caulis glaber aut paulo scabridus, interdum rubescens, saepe lineis purpureis longitudinalibus maculatus, verisimiliter $0.5^{-1} \mathrm{~m}$. altus. Folia ovato-cordata aut deltoidea, dentata, plus minusve lobata, utrinque setulis minutis adpressis scabra, petiolis adjectis $0.8-3 \mathrm{dm}$. longa, petiolis laminas subaequantibus aut excedentibus. Fructuum (P1. VII, f. I4; Pl. IX, ff. I3-I 5) corpus viridi-fuscum, demum crasso-oblongum et nitens, glandulosum sed parce pubescens, circ. $1.8 \mathrm{~cm}$. longum et 8-9 mm. crassum, aculeis brevibus armatum; rostris brevibus, crassis, pubescentibus, supra incurvatis, ad apicem saepe subhamosis, $3-5 \mathrm{~mm}$. longis; aculeis numerosis sed vix confertis, versus basim crassum glandulosis et saepe sparsim pubescentibus, supra tenuibus et glabris, ad apicem hamosis, 2-2.5 (rariter 3-3.5 aut etiam -4) $\mathrm{mm}$. longis.

Distribution: California.

Specimens examined: California: Suisun Marsh, in r893,Edw.L. Greene (Hb. Greene 19833 and 19834 ; type sheets); Lathrop, Harriet $A$. Walker 926 (Hb. Calif. 201 224); Suisun, eadem 973 (Hb. Calif. I 28022).

In Greene's Herbarium are two specimens to represent this rare and little known species, both of them collected by Greene himself at Suisun Marsh, and which may properly be taken as the types of the species. These have fruits just as described by Greene, except that they are more nearly oblong than he implied and had best not be described as "slightly obovate-oblong." Furthermore, they tend toward a greenish-brown in color, with some of the prickles becoming reddish.

The first specimen by Miss Walker (listed above) is, in our opinion, clearly $X$. palustre, but it shows an approach toward $X$. pennsylvanicum Wallr. in having prickles $3-3.5$ (a few even 4 ) $\mathrm{mm}$. long. Miss Walker's second specimen (no. 973), however, comes from the type locality and matches the two type specimens identically, both as to foliage and as to fruits. 


\section{Xanthium australe sp. nov. Pl. XIII.}

Caulis scabridus, plus minusve maculis purpureis parvis linearibus punctatus, verisimiliter $0.5^{-1} \mathrm{~m}$. altus. Folia petiolata, trinervia, deltoideo-cordata, saepe obscure lobata, dentata, utrinque setulis minutis adpressis vestita, petiolis adjectis $0.8-2 \mathrm{dm}$. longa, petiolis laminis subaequantibus. Fructuum (P1. VII, f. r5; Pl. IX, ff. r6-I8) corpus ovoideo-subglobosum, subsparsim glanduloso-pubescens aut glabratum, 0.9-I.I cm. longum et 6-7 mm. crassum (aut etiam $\mathrm{r} .3^{-1} .5 \mathrm{~cm}$. longum et 8-9 $\mathrm{mm}$. crassum, in specimine chilensi), aculeis confertis armatum; rostris attenuatis, rectis aut paulo inflexis, ad apicem subrectis aut uncinatis, infra pubescentibus, 6-9 $\mathrm{mm}$. longis; aculeis tenuibus, rectis aut paulo arcuatis, infra nec dense nec longe pubescentibus (in specimine chilensi quibusdam aculeis glandulosis et non pubescentibus), supra glabris, ad apicem uncinatis, 4-5 $\mathrm{mm}$. longis.

Distribution: Mexico, Paraguay and Chile.

Specimens examined: Tamaulipas: vicin. of La Barra, $8 \mathrm{~km}$. east of Tampico, at sea-level, Dr. Edward Palmer 275 (Hb. U. S. 4632I6, type). Paraguay: Asuncion, Thomas Morong 807 (Hb. N. Y.). Chile: Valparaiso, Dr. Mertens (ex Hb. Acad. Petrop., in $\mathrm{Hb}$. Gray).

The long fruiting beaks of this species suggested to us at first an affinity with the long-beaked West Indian form of X. chinense Mill. (X. longirostre Wallr.). A consideration, however, of the other fruit characters, as well as of foliage, shows no further relationships of a specific nature.

There is a slight possibility that this is the species which Vellozo had in mind when figuring his Xanthium brasilicum. But a careful inspection of Vellozo's plate (F1. Flum. ro: tab. 23. I827) shows it to be all too crude and lacking in definite detail to permit of satisfactory interpretation. ${ }^{1}$ Indeed, if the plate be at all accurate, it clearly represents some other species, for the characters of the bur as there shown are not those of $\mathrm{X}$. australe. ${ }^{2}$

${ }^{2}$ It is surprising to find that Baker (Martius Fl. Bras. 6" ${ }^{\mathrm{II}}$ I47. I884), notwithstanding the crudity of this plate, actually made it the basis for a new combination in nomenclature, X. strumarium L. var. brasilicum (Velloz.) Baker.

${ }^{2}$ We have seen no authentic material of the inadequately described $\mathrm{X}$. homothalamum of Sprengel (Neue Entdeck. I: 259. I820) from Brazil. We note that the name $\mathrm{X}$. homothalamum was entirely omitted by Baker from his treatment of Brazilian Xanthia (Martius Fl. Bras. 6"I: 147. I 884). Sprengel himself appears to have seen only scanty material of the plant ("Licet haut perfecta huius plantae exemplaria investigare potuerim," loc. cit., p. 260). He described the fruits briefly: "In ambitu sex aut octo drupae oblongae sulcatae, aculeis flavis uncinatis armatae. Singulae continent semen testa fusco-nigra obductum, in quo, sine albumine, embryo rectus oblongis cotyledonibus mediocriter carnosis, sedet." We find nothing in his description which might justify the reference of our $\mathrm{X}$. australe to $\mathrm{X}$. homothalamum. 
16. Xanthium echinatum Murr., Comm. Goetting. 6:32 and tab. 4 . $\mathrm{r} 783-1784$.

$X$. maculatum Raf., Amer. Journ. Sc. II I5I. I8Ig. ${ }^{1}$

Caulis scaber aut scabrido-hispidus, purpureo-maculatus, 3-6 dm. altus. Folia setulis adpressis scabra, plerumque cordata et obtuse lobata, obtuse et remote dentata aut serrata, petiolis adjectis $0.6-2.3$ dm. longa, petiolis laminas subaequantibus aut excedentibus. Fructuum (P1. VII, f. I6; P1. IX, ff. I9-2I) corpus crasso-ovale aut rare subglobosum, glanduloso-hispidum et aculeis subremotis armatum, demum I. 6-2 cm. longum et $0.8-1 \mathrm{~cm}$. crassum; rostris validis, incurvatis, ad apicem saepius hamosis, infra hispidis, $3-5 \mathrm{~mm}$. longis; aculeis tenuibus, rectis aut arcuatis, ad basim (aut usque ad medium) hispidis, supra calvis, ad apicem saepius hamosis, rostris subaequantibus.

Distribution: Quebec to New Jersey, also (apparently adventive) in Virginia, Ontario, North Dakota and Missouri.

SPECIMENS EXAMINED: QUEBEC: Longueuil, shores of St. Lawrence River, Brother Victorin I056 (Hb. Gray). OntaRIo: Ottawa, McKay Lake, Aug. 3, I9 I I, John Macoun (Can. Geol. Surv. no. 87545 in Hb. Mo., no. 7 I9897). MaINe: Prouts Neck, Sept., I898, Miss M. E. Blatchford (Hb. Gray). New HampShiRe: Newcastle, Little Harbor, Sept. I9, Igor, Emile F. Williams (Hb. Gray). Massachusetts: Boston, Savin Hill, Aug. 28, 1853, William Boott (Hb. Gray); Cape Cod, Hyannis Port, J. M. Greenman $36 I$ (Hb. Mo. 722293); Pemberton, sandy beach, Aug. 27, r897, B. L. Robinson (Hb. Gray); Nonquitt, Aug. 27, r888, E. L. Sturtevant (Hb. Mo. 8550I); Nonquitt, along sea-shore, Sept. 25, I888, idem (Hb. Mo. 85500); Dartmouth, roadside, Sept. 27, I889, idem (Hb. Mo. 85502); Revere, seashore sands, Aug. 22, I896, Emile F. Williams (Hb. Gray); Craigville, sandy roadside, Sept. 5, I898, idem (Hb. Gray); Scituate, seashore, Oct. 29, I899, idem (Hb. Gray); North Scituate, Sept. 6, I897, idem (Hb. Gray). RHodE IsLAND: Block Island, sandy sea-beach, southwest of Chagum Pond, Fernald, Hunnewell and and Long 10659 (Hb. Gray); without locality, in 1848 , Flint (Hb. Gray). New YoRK: Long Island, Rockaway Beach, Sept., I892, Dr. Smith Ely Jelliffe (Hb. Field 396974). New Jersey: Ocean County, Tom's River, sea-beaches, Kenneth K. Mackenzie I046 (Hb. Mo. 85503). Virginia: Cape Charles City, Canby and Rose 845 (Hb. U. S. 297952 ;- an anomalous form with burs glabrate but glandular upon the body, offering a strong superficial resemblance to $\mathrm{X}$. palustre Greene). Missouri: Allenton, Sept. 20, I89o, George W. Letterman (Hb. Mo. 775049;- a form with burs approaching those of X. italicum Mor.). NORTH DAK-

1 Torrey and Gray (Fl. N. Amer. 2: 295. 1843) described a variety of $\mathrm{X}$. echinatum Murr. (" $\beta$. prickles of the oval-oblong fructiferous involucre stouter and less crowded; leaves incisely lobed") from the "banks of Spirit Lake, head-waters of the Little Sioux River of the Missouri, Mr. Nicollet!" We have seen no authentic material of this variety: 
ora: Leeds, fields, Aug. I6-Sept. 6, I899, Dr. J. Lunell (Hb. Gray); Leeds, along running water, Aug. 28, I902, idem 82 (Hb. Gray).

This species was badly confused by Wallroth (Beitr. Bot. II : 239. I844) with the true $X$. orientale $L$. Indeed, many other botanists have fallen into similar errors, so that in literature we find $X$. echinatum erroneously equated with a number of entirely distinct species. Thus, for example, Thellung (Verhandl. Bot. Verein Brandenb. 50 ${ }^{\text {II }}$ I42-I44. 1908) actually gives as synonyms, $X$. italicum Mor., $X$. pennsylvanicum Wallr., X. riparium Lasch, X. campestre Greene ${ }^{1}$ and X. chinense Mill.

Murray's original description not only was very complete but was accompanied by a good plate. ${ }^{2}$ This plate shows the fruiting involucres to have an ovoid body, with short, rather remote prickles and very wide achenes (ff. I, 7 and 8). Thellung (loc. cit.) attempts to differentiate between Murray's description and plate, retaining the former and excluding the latter. But Murray's description ("............ Capsula ovalis, olivae magnitudinis, hirsuta, antice hamosa, hamis inflexis hispidis, vestita aculeis uncinatis, divergentibus, consertis, sursum et apice nudis, basi deorsum echinatis per setas rigidas albidas, rectiores; bilocularis..........") harmonizes perfectly, in our opinion, with the plate. Moreover, Murray himself stated that his plant, raised in 1783 , came from fruits sent him by Von Wangenheim, from New York. And it is precisely in the Atlantic coastal region beginning with New York and extending north and south that almost all the plants matching Murray's plate and description are found. Still further, Murray's reference to an olive in describing the fruits ("Capsula ovalis, olivae magnitudinis") is very significant. The plants cited in our foregoing list as representing true $\mathrm{X}$. echinatum, display, more than any other native species of Xanthium from Eastern North America, an open, plump, ovoid appearance to the body of the bur in such a way as to suggest an olive.

Numerous authors, like Thellung, have confused X. echinatum with the European X. riparium Lasch. All the European specimens of $X$. riparium examined by us (about fifteen sheets) have shown burs uniformly smaller, much narrower and with much smaller achenes. It appears to us probable that no European botanist, after examining several American specimens of X. echinatum, would hesitate to regard $\mathrm{X}$. riparium as distinct.

The plant described by Rafinesque (loc. cit.) as $X$. maculatum, came

1 Thellung had seen, for $\mathrm{X}$. campestre,only an incorrectly determined specimen, H. E. Brown 938 .

${ }^{2}$ Cf. Torr. and Gray (F1. N. Amer. 2: 295. 1843), who referred to this plate as "a good figure." But Thellung (loc. cit.), who clearly had a very incorrect conception of Murray's species, called the plate very bad ("pessima"). 
likewise from "the neighbourhood of New York"....... ("on Long Island, near the sea-shore and marshes"). Rafinesque distinguished his plant from $X$. echinatum, stating that $X$. echinatum had "oval fruits, with aggregated, echinate, and hooked thorns." Without doubt, he had in mind not the true $X$. echinatum Murr. but rather the plant later described by Moretti as X. italicum. The fruits of his X. maculatum he described as "generally solitary....... half an inch long, nearly cylindrical obtuse, with the two beaks scarcely perceptible and bent in, covered with short, thick and rough thorns, rather soft, and not uncinate." From these characters (especially the ones which we have emphasized with italics) as well as from the habitat given ("near the sea-shore and marshes"), we feel certain that by $X$. maculatum Rafinesque meant the plant which was really the true X. echinatum Murr.

i7. Xanthidm italicum Mor., Brugnatelli Giorn. fis., chim. Dec. II., 5: 326. I822; Reichenbach Iconographia Botanica $4: 22$, tab. 323. $\quad 1826$.

$X$. varians Greene, Pittonia 4: 59. $\quad$ I899.

$X$. glanduliferum Greene. loc. cit., 6r.

$X$. commune Britton, Manual 9r2. Igor.

X. Macounii Britton, loc. cit. $9 \mathrm{I} 3$. $^{1}$

Caulis ramosus, scaber, lineis atro-purpureis saepe maculatus, 3 -10 (-I8 fide Moretti) dm. altus. Folia cordata aut late ovata, lobata, dentata, utrinque setulis adpressis scabra, petiolis adjectis $0.8-3 \mathrm{dm}$. longa, petiolis laminis subaequantibus aut excedentibus. Fructuum (PI. VII, f. I7; Pl. IX, ff. 25-30) corpus nunc cylindricum, nunc oblong$\mathrm{um}$, nunc ovoideum, sed saepius late oblongum, facie exteriore glanduloso-pubescens et aculeis armatum, I.3-I.8 cm. longum, 6-8 mm. crassum; rostris plerumque incurvatis et ad apicem hamosis, hispidis, 5-7 mm. longis; aculeis saepius numerosis et tenuibus (rariter vel subremotis vel subcrassis), infra hispidis usque ad medium, supra glabris, ad apicem hamosis, $3-7 \mathrm{~mm}$. longis.

Distribution: Quebec, Connecticut and West Virginia to Saskatchewan, Washington, California and Oaxaca; southern Europe, Hawaiian Islands, and probably elsewhere.

${ }^{1}$ We are not able to determine satisfactorily the identity of $\mathrm{X}$. Cavanillesii Schouw (Ind. Sem. Hort. Haun.: 14. 1849; Ann. Sc. Nat. sér. III, I2: 357. 1849). Cavanilles' type plate (Cav. Icon. 3: tab. 221. 1794) cited by Schouw, shows the fruits glabrous, except, of course, as to beaks and prickles. If this plate be assumed to be accurate, then the plant figured was undoubtedly X. chinense Mill. If, as seems just as likely however, Cavanilles' plate was rather generalized and lacking in detail, as are many of his other plates, then his plant specimen probably possessed hispid-aculeate fruit and belonged to X. italicum. Cavanilles' description of the fruit (loc. cit., p. II) is devoid of details as to pubescence: "Fructus ovato-oblongus, pollicaris, estque drupa sicca, undique aculeis uncinatis tecta, apice bifida, cuius nux bilocularis." Schouw's own description of the fruit "Involucro fructigero ovali, inter aculeos et ad basin rostrorum hispidissimo; aculeis tenuiter subulatis, strictis, inferioribus retrorsum porrectis; rostris tenuibus, strictis, apice uncinatis"), based, however, upon a specimen from Buenos Ayres, by Didrichsen, might well pass for that of X. italicum. 
Specimens examined (partial list): Quebec: Leamy's Lake, Sept. I I, I89i, J. Macoun (Hb. N. Y.). New HAMPSHIRE: Charlestown, dry sandy open roadsides, Sept. I6, I899, B. L. Robinson (Hb. Gray). Vermont: Springfield, open dry sandy roadside, Sept. I6, I899, $B . L$. Robinson (Hb. Gray). New YoRK: Westport, shores of Lake Champlain, Sept. I5, I900, Dr. and Mrs. N. L. Britton (Hb. N. Y.; type of $X$. commune Britton); Sandy Hill, along Champlain Canal, Stewart $H$. Burnham 27 (Hb. Gray); Ogdensburg, Orra Parker Phelps I2I2, I2I3 and I2I4 (Hb. Gray); Hogansburg, banks of St. Regis River, eadem I2I6 (Hb. Gray). Connecticut: Plainfield, waste ground, Sept. 6, 1908, Bissell and Weatherby (Hb. Gray); Bridgeport, dry roadsides, E. H. Eames I (Hb. Gray). Pennsylvania: Lancaster, Oct. 7, I90I, A. A. Heller ( $\mathrm{Hb}$. Fieid 430065 ; Hb. Gray;-a form with burs suggesting $X$. pennsylvanicum). Lancaster, Dillerville Swamp, Sept. 24, I889, John K. Small (Hb. Field I68555). MARyLAND: shore of Chesapeake Bay, south of Havre de Grace, George H. Shull 39I (Hb. Gray; Hb. Mo. 85504). District of Columbia: shore of Potomac River, Sept. 3, I876, Lester F. Ward (Hb. U. S. 130953). VIrginia: along Potomac River, opposite Washington, D. C., Oct. 2, I904, E. S. Steele (Hb. U.S. 50466I). West VIRGINIA: Hendricks, dry places along Blackwater River, J. M. Greenman 537 (Hb. Field 345708; Hb. Gray; form matching type of $X$. commune Britt. very closely). Indiana: Bluffton, Sept. 9, I897, Charles C. Deam (Hb. Field I23387); vicin. Bluffton, idem 548, (Hb. Mo. 85437). Kentucky: locality not stated, Dr. C. W. Short, in 1842 (Hb. Gray). Illinors: East St. Louis, Stockyards, Sept. Io, 1886, H. Eggert (Hb. Mo. 75957I); sandy shore of Lake Michigan, Frank C. Gates 50 ( $\mathrm{Hb}$. Field 458182); Champaign County, Urbana Township, roadside, idem 2 II2 (Hb. Field 246297; an atypic form with prickles more remote); Winthrop Harbor, idem 3228 (Hb. Field 345082 and 45904I); Urbana, Sept. I9, IgoI, A. Gilkerson (Hb. Gray; atypic form with subremote prickles, approaching $\mathrm{X}$. pennsylvanicum Wallr.); Metropolis, banks of Ohio River, Aug. I4, I902, H. A. Gleason (Hb. Gray); Champaign, field, A. S. Pease I 3009 (Hb. Gray); Chicago, along sidewalk, Earl E. Sherf 3079 ( $\mathrm{Hb}$. Field 480735 and 480736); Chicago, along sidewalk, idem 308I (Hb. Field 480739). Iowa: Ames, $M$. Clapper ro (Hb. Gray; Hb. Mo. 8544I). Missourr: Courtney, in bottoms, B. F. Bush $18 \mathrm{r}_{3}$ (Hb. Mo. 8560I); Courtney, in bottoms, idem I9IO (Hb. Mo. 85458); Sheffield, idem 2216 (Hb. Mo. 85459); Webb City, in cultivated fields, E. J. Palmer IO39 (Hb. Mo. 756627); Webb City, waste places, idem I303 (Hb. Mo. 85509 and 75663I); Noel, Butler Creek, gravel bars, idem 4219 (Hb. Mo. 7 I6540). South Dakota: Watertown, John J. Thornber, Aug., I892, (Hb. Gray). NEBRASKa: 
Arcadia, Rev. J. M. Bates 5400 (Hb. Gray). Texas: Dallas, common on prairie, B. F. Bush II54 (Hb. Mo. 85477); San Antonio, Mr. and Mrs. J. Clemens 953 (Hb. Mo. 8087I7); Graham, J. Reverchon 3279 (Hb. Mo. 85473). SaskatchewaN: "South Saskatchewan," J. Macoun $4 I$ (Hb. Gray; a small-fruited form). Montana: Great Falls, Sept. I6, I885, F. W. Anderson (Hb. Chi. 360828). Colorado: Denver, common in damp alkaline soil, Alice Eastwood I54 (Hb. Gray; Hb. Calif. I48085); vicin. La Junta, Rose and Fitch 17507 (Hb. U. S. 760583). NEW Mexico: Nara Visa, Oct. 7, I9Io, Geo. L. Fisher (Hb. Mo. 818395); Mesilla Valley, Oct. I3, I906, Paul C. Standley (Hb. Mo. 85488); Mesilla Valley (Donna Ana County), College farm, Oct. I5, I901, E. O. Wooton (Hb. Mo. 85487); Mesilla Valley, Wooton and Standley 3129 (Hb. Field 223808). ARIzONA: Chiricahua Mountains, fields and sediments, J. C. Blumer I 487 (Hb. Field 242347; Hb. Gray; Hb. Mo. 85495; Hb. N. Y.); Fort Apache, Rev. Paul S. Mayerhoff 88 (Hb. Field II 3427). Washington: Spokane, Frank O. Kreager 537 (Hb. Gray); Spokane, along creek, Sept. I, I899, C. V. Piper (Hb. Gray); West Klickitat County, sandy banks of Columbia River, W. N. Suksdorf 1583 (Hb. Field 8975 ; Hb. Gray; Hb. Mo. 85499). California: Los Angeles, Dr. Hasse 4695 (Hb. N. Y.). SAN LuIs Potosi: San Luis Potosi, in sandy places about the city, Dr. J. G. Schaffner 388 (Hb. Gray). Sinaloa: near Mazatlan, Rose, Standley and Russell I4I33 (Hb. N. Y.; Hb. U. S. 636993). Guanajuato: Guanajuato, in i89i, Prof. $A$. Dugès (Hb. Gray). Morelos: near Cuernavaca, C. G. Pringle 7330 (Hb. Gray). Oaxaca: Valle de Etla, Rev. Lucius C. Smith 783 (Hb. Gray). CuBA: Güines, H. A. Van Hermann I66 (Hb. Field I70583).

Moretti's original description of $\mathrm{X}$. italicum is very full. According to his own account, for a long time he had considered his species to be $\mathrm{X}$. echinatum Murr. and had sent specimens so labeled to various eminent botanists such as De Candolle, Bertoloni etc. Finally he was forced to the conclusion that the species was distinct from X. echinatum Murr. and so he described it as new. He stated numerous characters in a minutely detailed way. We quote his description of the fruit: "Nux ovato-oblonga, undique aculeata, aculeis rigidis, apice simpliciter uncinatis, singulis undique echinatis. Rostra bina, patula, uncinata, quorum uncini convergentes. Styli basi laeviter complanati, hinc bifidi, e latere interiori uniuscuiusque rostri versus extremitatem prodeuntes."

Moretti's plants were collected in several localities along the Po River from Turin to Pavia. In the Bernhardi Herbarium (Hb. Mo. 85516) there exists a somewhat fragmentary and immature specimen with the inscription "Xanthium echinatum..................frequens Tau- 
rini." This is clearly one of Moretti's original specimens. In the De Candolle Herbarium at Geneva there exists a fine mature specimen collected by Moretti in the vicinity of Pavia, in r8rg. This likewise had been labeled Xanthium echinatum by Moretti. ${ }^{1}$ It matches well the Turin specimen from the Bernhardi Herbarium and both of these specimens agree perfectly with the plate published (from a specimen sent by Moretti) by Reichenbach (loc. cit.) in $1826 .^{2}$

$X$. varians Greene, while somewhat atypic in that its fruiting prickles are slightly stouter, is easily seen to be a form of this species. $X$. Macounii Britton is best considered as likewise a form of X. italicum. Unfortunately, the single type specimen on which the description of $X$. Macounii was based has immature fruits. These point, however, to a somewhat atypic, rather sparsely aculeate form of X. italicum, such as may be found growing occasionally among plants of the typical form. Of $X$. glanduliferum Greene we have seen two specimens of the type collection ( $\mathrm{Hb}$. Can.; $\mathrm{Hb}$. Greene r9844). These would seem at first to be closer to $\mathrm{X}$. echinatum Murr. But the size and shape of the achene and the character of the foliage all indicate a closer affinity with $X$. italicum. At best, $X$. glanduliferum is probably to be considered as only another of the mutant forms produced occasionally by $\mathrm{X}$. italicum.

With $\mathrm{X}$. italicum must be placed also $X$. commune Britton, originally described from Westport, New York. The type specimen of $X$. commune has the burs somewhat immature. These match closely those of the type material of $X$. glanduliferum Greene. We have seen several cases (e.g., Greenman 537, Hb. Gray) in which exactly the same form of burs appeared along with other burs that were topical of $\mathrm{X}$. italicum. But whether this divergence from the typical form was due to hybridization or to mere variation we are unable to state. ${ }^{3}$

\section{Xanthium acerosum Greene, Pittonia 4: 63. I899.}

Caulis flexuosus, lineis purpureis longitudinalibus saepe maculatus. supra scaber, infra fere glabrescens, verisimiliter circum $4-9 \mathrm{dm}$. altus, Folia late subcordato-ovata, obtusa, crenato-dentata, utrinque setulis minutis adpressis scabra, petiolis adjectis $0.7^{-2} \mathrm{dm}$. longa, petiolis laminis subaequantibus. Fructuum (Pl. VII, f. I8; PI. IX, ff. 22-24) corpus cylindricum, moderate glanduloso-pubescens, aculeis subremotis armatum, I. $-1.9 \mathrm{~cm}$. longum et $6-7 \mathrm{~mm}$. crassum; rostris tenuibus, attenuatis, molliter pubescentibus, subrectis aut irregulariter incurvatis, ad apicem minime hamosis, 7-8 $\mathrm{mm}$. longis; aculeis vix numerosis,

\footnotetext{
1 We rely upon a large and excellent photograph of the sheet, furnished us through the great kindness of the late M. Casimir De Candolle.

${ }^{3}$ We have seen various European specimens collected, since Moretti's time, in Italy, Corsica, Sardinia etc. Some of these were already labeled X. italicum.
}

${ }^{3}$ For distinctions between $\mathrm{X}$. italicum and $\mathrm{X}$. pennsylvanicum, see $\mathrm{p}$. 34 . 
gracilibus, remisse fere usque ad apicem pilis mollibus longiusculis vestitis, rectis aut subrectis, ad apicem nunc dimidia parte eorum hamosa, nunc vix uno aculeo hamoso, plerumque $6-9 \mathrm{~mm}$. longis.

Distribution: New York (where apparently adventive); Wisconsin, North Dakota and Nebraska.

Specimens examined: New York: Whitehall, Dresden Trestle, Stewart H. Burnham 28 (Hb. Gray). Wisconsin: Brown County, Preble, Baird's Creek, Sept. 26, r899, J. H. Schuette (Hb. Gray; Hb. U. S. 751759; the latter a rather immature and indistinctive specimen). North Dakota: near Fargo, Sept. 4, 1893, Edward L. Greene (Hb. Greene 19835;- type); Minot, along Souris River, Dr. J. Lunell 80 (Hb. Gray); Burleigh County, Bismarck, Aug. 23, r9r3, idem (Hb. Greene 23707). Nebraska: Red Cloud, Rev. J. M. Bates 4747 (Hb. Gray).

It is with some hesitation that this species is here retained. The fruiting burs, when slightly immature, resemble those of $\mathrm{X}$. italicum. When fully ripe, they appear to be intermediate between those on certain forms of $\mathrm{X}$. pennsylvanicum Wallr. and those on certain forms of $\mathrm{X}$. speciosum Kearney. The brown, ripe burs have a body more or less narrowly cylindrical; the prickles are mostly long and very delicate; their hairs are soft and fine. However, as the specimens examined agree very well among themselves, interference with the status of the species seems scarcely wise or desirable at the present time.

19. Xanthium OVIForme Wallr., Beitr. Bot. I ${ }^{11}$ : 240. 1844.

$X$. silphiifolium Greene, Pittonia 4: 60. 1899 .

Caulis simplex, infra levis, supra scabridus, $3-7 \mathrm{dm}$. altus. Folia membranacea, indivisa, deltoideo-ovata, interdum vix trinervia, inaequaliter sinuato-dentata, utrinque concoloria et setulis minutis adpressis albidis aspera, ad basim vel orbiculata vel truncata vel cordata, petiolis adjectis $0.7^{-2} \mathrm{dm}$. longa, petiolis laminis subaequantibus. Fructus (Pl. VII, f. I9; Pl. X, ff. I-3) non multi, demum maximi, plerumque singulatim dispositi; fructuum corpore oblongo-ovato, glanduloso-hispido aut rariter glabriusculo, aculeis armato, demum circum $2 \mathrm{~cm}$. longo et i. $2 \mathrm{~cm}$. crasso; rostris validis, crassis, hispidis, supra incurvatis, ad apicem valde uncinatis, circum $8 \mathrm{~mm}$. longis; aculeis remotis aut subremotis (aut fere confertis), validis, arcuatis et corniformibus, fere usque ad apicem ferrugineo-hispidis (saltem ad tergum et latera), ad apicem valde hamosis, ad faciem ventralem inferioribus plerumque canaliculatis, $\left(5^{-}\right) 7^{-10} \mathrm{~mm}$. longis.

Distribution: Washington and probably Oregon; also adventive, formerly at least; in southwestern Illinois.

Specimens examined: Washington: Wawawai, C. V. Piper 3575 (Hb. Gray); Kittitas County, Rock Island, along water-courses, Sandberg and Leiberg 446 (Hb. Gray); West Klickitat County, Sept. 28, I883, sandy banks of the Columbia River, W. N. Suksdorf (Hb. Field 
97447 and 2 rr 249; cotypes of $X$. silphiifolium Greene); without locality, in 1879 , idem (Hb. Gray); West Klickitat County, bottom lands of the Columbia River, idem I89 (Hb. Gray). Illinols: East St. Louis, banks of the Mississippi River, Sept., 1847, Dr. George Engelmann (Hb. Mo. $8555^{2}$; form close to X. speciosum Kearney); cultivated by Asa Gray, in botanical garden, Cambridge, Massachusetts, Oct., r848, from $I 7 I$ and I7Ia of Dr. George Engelmann, collected presumably in September, 1847 , at East St. Louis, I11., with the preceding specimen (2 sheets in Hb. Gray; more typical than Engelmann's own specimen).

Greene (loc. cit.), in proposing nine species of Xanthium as new, among them $X$. silphiifolium, laid no claims to a very profound knowledge of the genus as a whole. Thus, with reference to Wallroth's monographic treatment of Xanthium, he says: "At present I know nothing as to what his X. laevigatum, pungens, pennsylvanicum, xanthocarpum or oviforme are. Presumably, however, they all belong to the Atlantic slope of the continent. Little or nothing was known of this genus as represented west of the Mississippi in the year 1842 [sic]. As all the following are from far-western regions, I shall, in naming them as new, incur small risk of becoming a manufacturer of synonyms."

Regarding three of these species, viz. $X$. pungens, $X$. pennsylvanicum and " $X$. xanthocarpum," there need be no doubt as to the forms referred to by Wallroth ( $c f$. pp. 22, 3 I and I5). Regarding X. laevigatum, we ourselves are unable as yet to reach positive conclusions. The case of $\mathrm{X}$. oviforme, however, lends itself to very definite treatment. Wallroth's description of this species is decisive and clear. In speaking of the fruits he says (loc. cit.): "fructibus sessilibus solitariis utrinque aequaliter rotundatis oviformibus (maximis), aculeis confertis validis corniformibus basi pilis articulatis ferrugineis densis vestitis cum rostris intus contractis teretibus figura, vestitu et longitudine subconformibus deliquescendo veluti obliteratis." We have also his footnotes regarding the fruits. The first one says: "5) eiformige, in Vergleich zur Pflanze (d.h. dem vorliegenden Probestūcke) sehr grosse, mit den Stacheln dem Umfang einer kleinen Wallnuss oder Musskatennuss gleichende Frucht."

1 Two other footnotes in connection with the fruits are given by Wallroth. We reproduce them verbatim herewith: "6) besonders stark ausgebildete, dichtstehende, $2^{\prime \prime \prime}$ lange Stacheln, welche bis über die Halfte mit dicht-und abstehenden, gegliederten Haaren umstarrt sind, am oberen Theile aufwărts, in der Mitte etwas abwärts und am Grunde rückwärts gerichtet sind und den ganzen Fruchtkőrper allenthalben dich und gleichmässig umstarren;

"7) mit den Stacheln fast gleichförmige, nur doppelt so starcke, nach oben rinnenförmig ausgehöhlte Stacheln, welche wegen gegenseitiger Aehnlichkeit mit den Stacheln gleichsam zu verschwinden oder im Vergleich mit anderen Arten $z u$ fehlen scheinen." - The grooved ventral surfaces exhibited by certain of the large basal prickles on the fruits of this species seem indeed an unique character. 
A comparison of Wallroth's Latin description with the others in his monograph shows two outstanding features for his $\mathrm{X}$. oviforme. The fruits were very large and were covered with strong, horn-shaped prickles, these densely clothed at their base with jointed, reddish hairs. Furthermore, Wallroth based his species directly upon Hooker's Xanthium canadense from North America ("X. Canadense Hook. in lit. (herb. general berol.), nec Herm., Mill. et Linn. Angeblich in Nordamerika und vermuthlich in Canada.").

Thus, Wallroth had seen a plant in Berlin labeled " $X$. canadense" by Hooker, but which appeared distinct from all other specimens because of its mammoth burs and their horn-shaped prickles. On reference to Hooker's Flora Boreali-Americana, a work published in r840 and which Wallroth appears not to have seen, we find the basis of Wallroth's species. Hooker (loc. cit. 308), instead of giving an extended range or list of stations as in the case of many other species, gave merely, "Hab. Canada? North-West coast of America. Douglas." So the plant determined by Hooker as $X$. canadense was a plant collected by Douglas along the northwest coast of (North) America. ${ }^{1}$ But it was in this same region that the type of $X$. silphiifolium Greene was obtained. Greene's type was collected by Suksdorf, on the banks of the Columbia River, ${ }^{2}$ September, 1883 . While this type itself (in Hb. U. S.) is at present inaccessible to us, we have seen the two excellent cotypes in the Herbarium of Field Museum and also the two other specimens by Suksdorf in Gray Herbarium. These all agree well with each other in having large, coarse burs, with very strong, elongate, reddish-hispid, horn-shaped (arcuate), hooked prickles and somewhat similar beaks; the lower prickles on each bur tend to be strongly grooved upon the ventral face. The specimen collected by Suksdorf on bottom lands of the Columbia River (no. 189) is particularly instructive. It is accompanied by one mature bur, much larger than the rest, a bur such as most collectors might shrink from trying to press. This bur is really of gigantic proportions, having a size observed by us so far in only two other species (X. campestre and $\mathrm{X}$. speciosum). The body proper is $2.3 \mathrm{~cm}$. long and about $\mathrm{I} \mathrm{cm}$. thick. The prickles and beaks measure from $8 \mathrm{~mm}$. to ro $\mathrm{mm}$. in length, giving the bur a total expanse of 3.9 $\mathrm{cm}$. in length and about $2.8 \mathrm{~mm}$. in width.

Without question, it was this large-fruited form of Xanthium that

${ }^{1}$ Had Hooker seen plants of this species from other collections it is clear that he would have cited them, since his citations of range appear in each case to be as complete as his data at that time would permit.

\footnotetext{
${ }^{2}$ An examination of Hooker's text shows that a large proportion of the other Douglas plants studied by Hooker had likewise come definitely from the banks of the Columbia River.
} 
was the basis of Wallroth's X. oviforme and the identity of the species is thus seen to be settled too clearly to permit of its name being displaced by the more recent name $X$. silphiifolium. ${ }^{1}$

\section{Xanthium Speciosum Kearney, Bull. Tor. Bot. Club 24: 574, I897. \\ X. bubalocarpon Bush, Rept. Missouri Bot. Gard. 17: 123, I906. ${ }^{2}$}

Caulis erectus, robustus, ramosus, ad basim demum $2.5 \mathrm{~cm}$. crassus, plus minusve (infra obtuse et supra acute) quadrangulatus, supra lineis purpureis maculatus, papilloso-scabridus praesertim supra, I-I.5 m. altus. Folia late triangulato-ovata, obtuse et non profunde 3-5-lobata, dentata, crassiuscula, ad basim cordata, utrinque setulis aut papillis minutis adpressis scabra, petiolis adjectis $\mathrm{I}-3.5 \mathrm{dm}$. longa et $0.8-2.2 \mathrm{dm}$. lata, petiolis laminis subaequantibus. Fructus (P1. VII, f. 20; P1. X, ff. 4-6) maximi, ovoidei aut conici; corpore ovato-cylindrico, vix aspectabili, glanduloso-pubescenti, aculeis armato, demum circum $2-2.3 \mathrm{~mm}$. longo et 7-8 $\mathrm{mm}$. crasso; rostris attenuatis, hispidis, subrectis aut incurvatis, ad apicem hamosis, 6-I I mm. longis; aculeis confertis, subtenuibus, besse inferiore aut dimidio inferiore hispido, versus apicem levibus, ad apicem hamosis, plerumque $7-9 \mathrm{~mm}$. longis; toto fructu (aculeis et rostris adjectis) demum 3-4 cm. longis et 2-2.5 ( -3 ex descriptionibus Kearneyi et Bushii) cm. latis.

Distribution: Tennessee to South Dakota, Texas and Mexico; adventive in Maine and Vermont. ${ }^{3}$

Specimens examined: ${ }^{4}$ MaIne: North Berwick, wool-waste heap, Sept., I895, John C. Parlin (Hb. Gray). TennesseE: Cocke County, between Paint Rock and Del Rio, along French Broad River, Thos. $H$. Kearney, Jr., 785 (Hb. Greene I9829; Hb. Mo. 85550; Hb. N. Y.; cotypes). Missouri: Cass County, roadside, prairie, Aug., I869, G. C.

1 Since the above was written, we have been very fortunate in receiving from the Herbaria of the British Museum of Natural History and the Royal Botanical Gardens at Kew, excellent photographs of the Douglas plants. Our conclusions, as presented above, are seen to be confirmed most emphatically. Both specimens match precisely the Suksdorf material of $X$. silphiifolium. The inscription on the British Museum sheet, as copied for us, reads, "X. strumarium Willd. Sandy island and banks of the Columbia Douglas 1825 Xanthium canadense Spreng. Hook Fl. Bor.Am. 1. p. 308." That upc a the sheet at Kew (a sheet originally in Bentham's private herbarium) reads, "Xanthium canadense Spr. Hook Fl. Bor. Am. I. 308. Am. bor. occ. Douglas 1829 [sic] X. oviforme Wallr. cotype."

${ }^{2}$ Piper (Contrib. U. S. Nat. Herb. Ix: 550. 1906) has referred $X$. silphiifolium Greene to this species. But, as will be apparent from the foregoing paragraphs (Cf. X. oviforme, p. 44) if $X$. silphiffolium, which is synonomous with $X$. oviforme, shall subsequently be proved conspecific with $\mathrm{X}$. speciosum, then, by the same proof, $\mathrm{X}$. speciosum will have been shown to be synonomous with $\mathrm{X}$. oviforme.

${ }^{3}$ Cf. footnote $\mathbf{r}$, p. 27.

- We have seen two specimens by H. Eggert, one at least from Illinois (presumably at East St. Louis), collected Sept. 13, 1874 (Hb. Gray; Hb. Mo. 8538r). These appear to be $\mathrm{X}$. speciosum, but the prickles are subremote and rather stout and suggest $X$. oviforme Wallr. very strongly. 
Broadhead (Hb. Mo. 85553). Arkansas: Fulton, B. F. Bush 2408 (Hb. Mo. 85375). South Dakota: Deadwood, waste ground, alt. r430 m., John Murdoch, Jr., 4334 (Hb. Gray). Kansas: Kiowa County, low ground, A. S. Hitchcock 726 (Hb. Gray; Hb. Mo. 85525). Окцанома: Hugo, moist limestone soil, E. J. Palmer 90I5 (Hb. Mo. 79448r). Texas: Dallas, prairie, B. F. Bush II85 (Hb. Gray; Hb. Mo. 85380; type specimens of $X$. bubalocarpon Bush); Pease River, near Vernon, salt bottoms, Sept. r8, r903, H. Eggert (Hb. Mo. 85558 and 85559); Dallas, Oct. ro, year not stated, J. Reverchon (Hb. Mo. 85557); Coombs Branch, Aug. 24, I90I, idem (Hb. Mo. 85556 and 85562); Coombs Branch, Oct. 9, year not stated, idem, (Hb. Mo. 85479); Dallas, prairie, Aug. 30, rgor, idem (Hb. Gray; Hb. Mo. 85378); Dallas, prairie, idem 2580 A (Hb. Mo. 85379); Luck's Mill, Aug. 25, year not stated, idem (Hb. Mo. 85560 and 8556r); Oak Cliff, wastes, Aug. 30, rgor, idem (Hb. Mo. 85376 and 85377 ). ${ }^{1}$

While appearing in rare cases to intergrade or perhaps hybridize with $\mathrm{X}$. oviforme Wallr., X. speciosum seems, nevertheless, on the whole to be worthy of retention as a distinct species. It is apparently best distinguished from that species by the closer, more slender and less arcuate prickles, which do not suggest horns, and by a tendency of the entire involucre, when mature, toward a yellowish or yellowish-brown color rather than toward the dark-reddish color shown in $\mathrm{X}$. oviforme.

The several sheets of type material (Kearney 785) that we have examined are of a slightly immature stage and the burs are not fully ripened. But Kearney (loc. cit.) described the burs as " $2.5-4 \mathrm{~cm}$. long, $2.5-3 \mathrm{~cm}$. wide (including the prickles)" and, as some of the slightly immature burs are observed by us on the type material to have become $3.5 \mathrm{~cm}$. long and $2.5 \mathrm{~cm}$. wide (including the prickles), it is certain that Kearney's measurements correctly represent the mature fruits.

In describing his $X$. bubalocarpon, Bush (loc. cit.) stated: "This very distinct species is more nearly related to $X$. speciosum Kearney, but is easily distinguished from that species by the much larger burs which are of an entirely different shape." However, on reading his description, we find given the measurements " $2.5-4 \mathrm{~cm}$. long, including the prickles." It is seen that these measurements are practically identical with those given by Kearney for X. speciosum. And, indeed, when we compare the excellent type material of $X$. bubalocarpon (Bush r 185 ) with that of $X$. speciosum, we can detect no specific difference.

${ }^{1}$ We have seen no typical material of $\mathrm{X}$. speciosum from Mexico. Certain somewhat anomalous forms from there appear, however, to be best regarded as belonging to this species (e.g., J. N. Rose 2433, near San Juan Capistrano, Zacatecas, Hb. U. S. 301344; Rose, Painter and Rose 0952, near Tehuacan, Puebla, Hb. U. S. 453446). 
The two are well connected, furthermore, by the various other specimens of differing stages of maturity examined by us and cited above.

2r. Xanthium campestre Greene, Pittonia 4: 6r. 1899.

Caulis saepe lineis purpureis brevibus maculatus, supra scabridus, 5-8 dm. altus. Folia subcrassa, subdeltoidea, dentata aut serrata, non perspicue lobata, ad basim truncata aut cordata, supra scabra, infra scabro-pubescentia, petiolis adjectis $6-\mathrm{I} 7 \mathrm{~cm}$. longa, petiolis laminis subaequantibus. Fructus (Pl. VII, f. 21 ; Pl. X, ff. 7-8) maximi, maximam partem singulatim dispositi, ovoideo-conici; corpore non saepe aspectabili sed aculeis plerumque numerosis et densissimis armato, demum circ. $2.3^{-2.6} \mathrm{~cm}$. longo et $\mathrm{I}-\mathrm{I} .3 \mathrm{~cm}$. 'crasso; rostris late divergentibus, infra crassis et pubescentibus, supra glabratis et tenuiter hamosis, 6-7 mm. longis; aculeis teretibus, arcuatis, infra (demum ferrugineo-) hispidissimis, supra glabris et ad apicem hamosis, circum $5 \mathrm{~mm}$. longis; toto fructu (aculeis et rostris adjectis) demum $2.8-3.5 \mathrm{~cm}$. longo et $2-2.5 \mathrm{~cm}$. lato.

Distribution: California.

Specimens examined: California: Chico, June 27, 1890, Edward L. Greene (Hb. Greene r9837; type); Chico-Hamilton Road, $9.5 \mathrm{~km}$. northwest of Chico, A. A. Heller II620 (Hb. Cålif. r79073; Hb. Field 426983; Hb. Gray; Hb. Greene 51204; Hb. Mo. 748r45; Hb. N. Y., a more mature specimen, with the burs just turning reddish in color.)

This species is distinguished from most others by the great size of its burs, these coming to have, when well-developed, an expanse (including the beaks and prickles) of about $3.5 \mathrm{~cm}$. in length and $2.5 \mathrm{~cm}$. in width. In Greene's type specimen, the prickles are remote enough to permit a view of the body of the bur. The several somewhat immature specimens by Heller have the prickles more densely grouped together, leaving the body mostly concealed. The burs have a decidedly yellowishgreen color until nearly mature, when they turn to a reddish color, rather closely resembling those of $\mathrm{X}$. oviforme Wallr. 



\section{INDEX}

Acanthoplia Wallr. 14

Acanthoxanthium DC. 14

Acanthoxanthium spinosum Fourr. I4

Anoplia Wallr. I5

Campylorrhyncha Wallr. I5

Euxanthium DC. 15

Lappa canadensis minori Ray 26

Orthorrhyncha Wallr. I5

Xanthium L. 12 abyssinicum Wallr. 16 acerosum Greene 9, 43 acutilobum M. \& S. 35 acutum Greene 3I, 9, 33, 34, 35

affine Greene 3I, 9, 33, 35

ambrosioides H. \& A. I7

americanum Walt. 20, 10, 22, 23

antiquorum Wallr. I6, I7, 20

arcuatum M. \& S. 25

australe M. \& S. 37

brasilicum Velloz. 37

brevirostre Wallr. 16, I7

bubalocarpon Bush 47,48

californicum Greene 31, 9, 33, 34, 35, 36

calvum M. \& S. 35

campestre Greene 49, 39

canadense Mill. 20, I 7, 46

carolinense Dill. I7

Cavanillesii Schouw. 40

cenchroides M. \& S. 30

chinense Mill. I7, 10, 23, 25, 26, 27, $32,37,39,40$

commune Britt. 40, 29, 4I, 43

Wootoni Cockll. 28

crassifolium M. \& S. 35

crassum Raf. I6

cuneatum Moen. 26

curvescens M. \& S. 25

cylindricum M. \& S. 23, 9

discolor Wallr. 16, 17, 21

echinatum Murr. 38, 10, 22, 23, 33, 42,43
Xanthium

elatius a majus americanum Moris. 26 eriocarpon Wallr. I7

glabratum Britt. I7

glanduliferum Greene 40, 9, 43

globosum Shull 23, 9, 10

homothalamum Spr. 37

inaequilaterum DC. 17

inflexum Mack. \& Bush 30

italicum Mor. 40, 10, 27, 33, 34, 38, 43

laevigatum Muhl. 45

leptocarpum M. \& S. 28, 26, 27

leucocarpon Wallr. 17

longirostre Wallr. 17, 22, 37

Macounii Britt. 40, 43

macrocarpum DC. 26, 10, 27

glabratum DC. 17

maculatum Raf. 38, 16, 39

majus canadense Herm. 26

occidentale Bertol. 17.22. 23

oligacanthum Piper 28

orientale L. 26 , 10, I6, 20, $25,27,39$

oviforme Wallr. 44, 47, 48, 49

palustre Greene 36

pennsylvanicum Wallr. 31, I0, 22,

$25,36,39,41,44,45$

eglandulosum Wallr. 31, 34, 32

glandulosum Wallr. 3I, 34

pensylvanicum Wallr. 3 I

priscorum Wallr. 17, 16

pungens Wallr. 17, 22, 23, 45

riparium Lasch. 39

Roxburghii Wallr. 16, 17

saccharatum Wallr. 3I, 34

silphiifolium Greene 44, 45, 46, 47

speciosum Kearn. $47,27,44$

spinosum L. I4, 10

strumarium L. I6, 10, 17, 22

antiquorum Ball. 16

brasilicum Bak. 37

undulatum Raf. 16

varians Greene 40, 43

Wootoni Cockll. 28

xanthocarpon Wallr. I4, I5, 45 





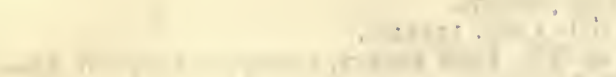

$$
\text { . }
$$$$
\text { . }
$$

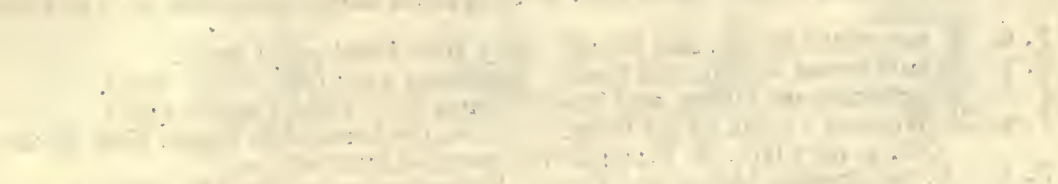$$
\begin{array}{lll}
0 \\
0
\end{array}
$$

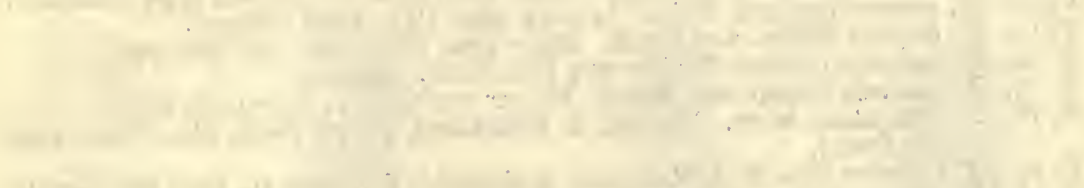

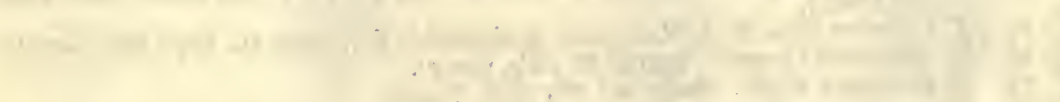

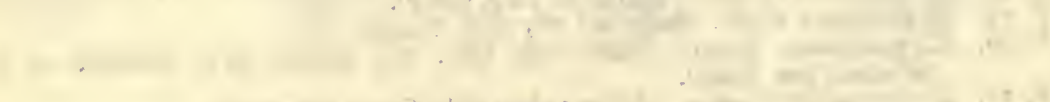

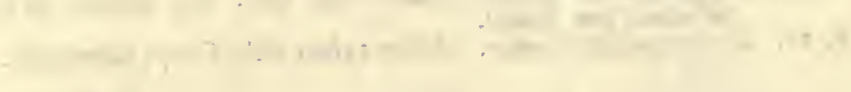




\section{Plate VII.}

F. I. X. spinosum L. Eggert (Hb. Mo. 720835).

F. 2. X. strumarium L. Brandegee (Hb. Calif. 131246).

F. 3. X. chinense Mill. Greenman 47 (Hb. Field 189512; topotype; atypic in having prickles slightly pubescent at base.)

F. 4. X. cylindricum Millsp. and Sherff. Small and Huger (Hb. Field 401312; type).

F. 5. X. globosum Shull. Shull ( $\mathrm{Hb}$. Field 477328; lineal descendant of type material).

F. 6. X. arcuatum Millsp. and Sherff. Lucy (Hb. Field 4953; type).

F. 7. X. curvescens Millsp. and Sherff. Eggleston I420 (Hb. Gray; type).

F. 8. X. leptocarpum Millsp. and Sherff. Jones (Hb. Field $430860 ;$ type).

F. 9. X. Wootoni Cock11. ex De Vries. T. D. A. Cockerell, Las Vegas, New Mexico, Oct. 4, I90I (Hb. N. Y.; authentic material from author),

F. 10. X. cenchroides Millsp. and Sherff. Reverchon 2332 (Hb. Mo. 85563; type).

F. II. X. inflexum Mack. and Bush. Bush I9I6 (Hb. Mo. 85520; type material).

F. 12. X. pennsylvanicum Wallr. Lansing 3532 ( $\mathrm{Hb}$. Field 346590).

F. I3. X. calvum Millsp. and Sherff. Baker I 760 (Hb. Calif. I31236; type).

F. I4. X. palustre Greene. Walker 973 (Hb. Calif. I28022).

F. I5. X. australe Millsp. and Sherff. Palmer 275 (Hb. U. S. 463216; type).

F. I6. X. echinatum Murr. Miss M. E. Blatchford, Prouts Neck, Me., Sept., I 898 (Hb. Gray).

F. 17. X. italicum Mor. B. L. Robinson, Springfield, Vt., Sept. I6, I899 (Hb. Gray).

F. I8. X. acerosum Greene. Lunell 80 (Hb. Gray).

F. 19. X. oviforme Wallr. Suksdorf I89 (Hb. Gray).

F. 20. X. speciosum Kearn. Bush II85 (Hb. Mo. 85380; type material of $X$. bubalocarpon Bush).

F. 2I. X. campestre Greene. Heller II629 (Hb. Gray; topotype). 


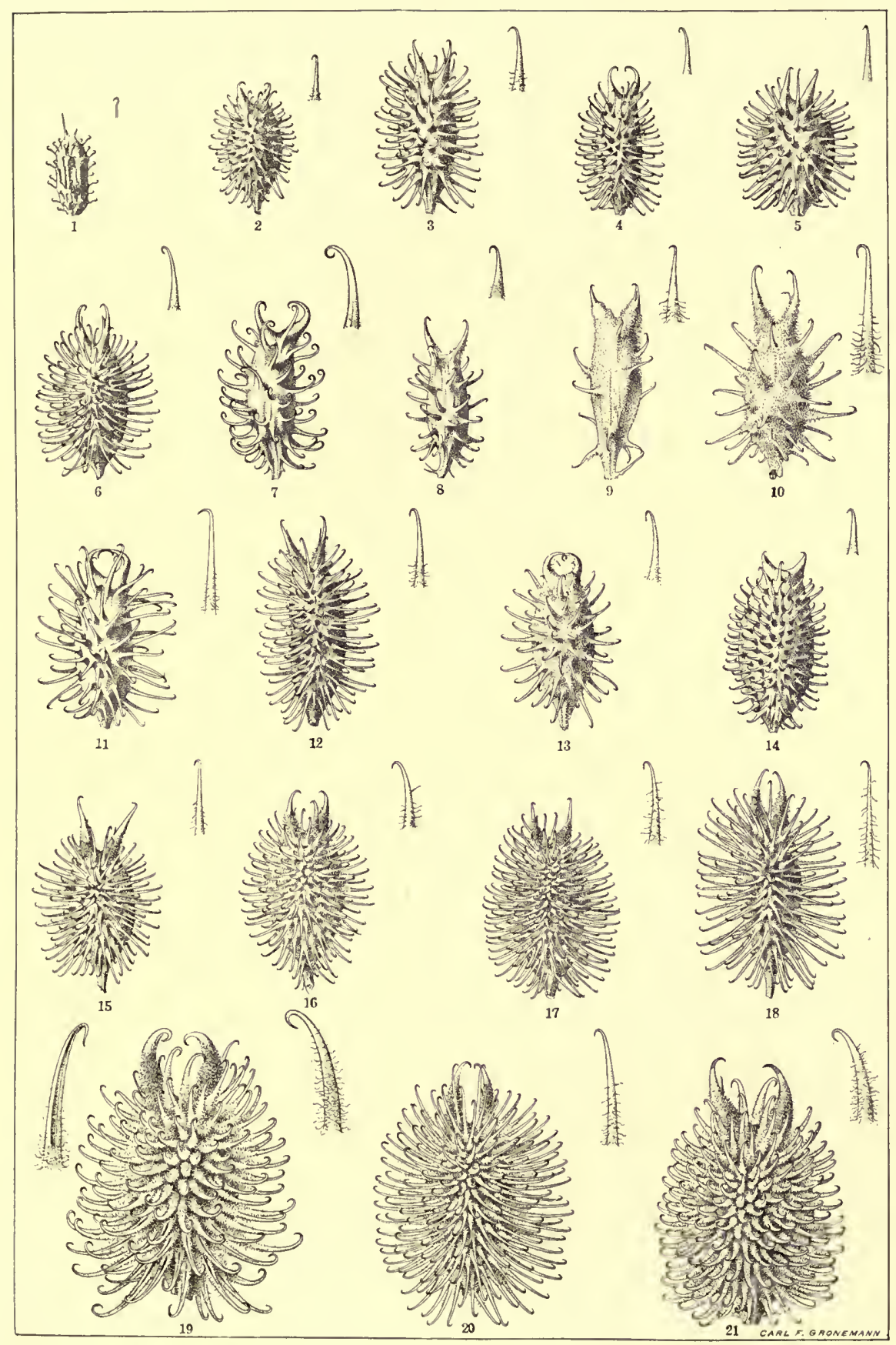

FRUITS OF XANTHIUM (Natural size) 




\section{Plate VIII.}

X. spinosum $\mathrm{L}$.

F. I. C. R. Orcutt, Port Harford, Calif., Nov. 23, 1886 (Hb. Mo. 85586).

F. 2. Heller I 2655 (Hb. Mo. 802945).

F. 3. Griffiths 7344 (Hb. Mo. 85583).

X. strumarium $\mathrm{L}$.

F. 4. Hb. Schlagintweit, drained lake basin of Kashmir, vicin. Srinagger, prov. Kashmir, India, Oct. 2-20, I856 (Hb. Gray).

F. 5. T. Thomson, Plan. Ganget. Sup., India Orient. (Hb. Gray).

F. 6. Fernald, Crescent Beach, Revere, Mass., Oct. 20, 1912 (Hb. Gray).

F. 7. W. Schimper 1343, in agris Sorghi pr. Sabra Abyssinia (Hb. Gray; cotype of $X$. abyssinicum Wallr.).

F. 8. Kotschyi iter nubicum 319, ad ripas Nili albi prope Chartum in provincia X. chinense Mill. Sennar (Hb. Gray; cotype of X. antiquorum Wallr.).

F. 9. Rose, Fitch and Russell 4351 (Hb. U. S. 760483, topotype of $X$. occidentale Bertol.).

F. Io. Greenman 47 (Hb. Field 189512, topotype).

F. II. Brown and Britton 374 (Hb. Field 203890).

F. 12. Bush I348 (Hb. Mo. 85428).

F. 13. Phelps 989 (Hb. Gray).

Ff. I4 and 15. Anonymous (Hb. Fla. Agricult. Coll. no. I279 in Hb. Field, no. 234909).

$\mathrm{X}$. cylindricum Millsp. and Sherff.

Ff. I6, I7 and 18. Small and Huger (Hb. Field 401312, type).

Ff. I9 and 2o. (Hb. N. Y., cotype).

$\mathrm{X}$. globosum Shull.

F. 21. Shull (Hb. Field 477328 , lineal descendant of type material).

Ff. 22 and 23. Shull (Hb. Field 477326, topotype identical with type).

$\mathrm{X}$. arcuatum Millsp. and Sherff.

Ff. 24, 25 and 26. Lucy (Hb. Field 4953, type).

X. curvescens Millsp. and Sherff.

Ff. 27, 28 and 29. Eggleston 1420 (Hb. Gray, type).

$\mathrm{X}$. leptocarpum Millsp. and Sherff.

Ff. 30, 31 and 32. Jones (Hb. Field 430860, type).

$\mathrm{X}$. Wootoni Cockll. ex De Vries.

F. 33. Deane, South Boston, Mass., Oct. 4, I909 (Hb. Williams in Hb. Gray).

F. 34. Horner B 272 ( $\mathrm{Hb}$. Gray).

F. 35. Piper (Hb. N. Y., cotype of $X$. oligacanthum Piper).

F. 36. Cockerell (Hb. Gray, author's material).

X. cenchroides Millsp. and Sherff.

Ff. 37 and 38 . Reverchon 2332 (Hb. Mo. 85564, cotype).

F. 39. Reverchon 2332 (Hb. Mo. 85563, type). 


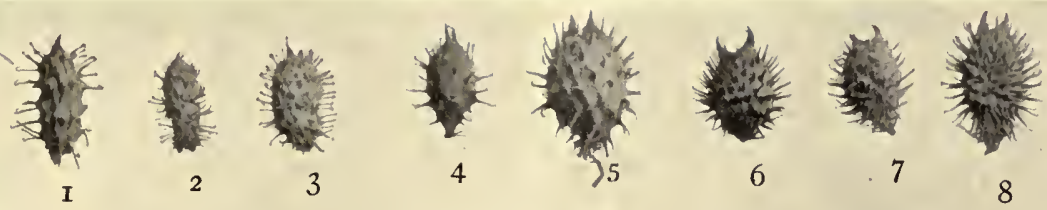

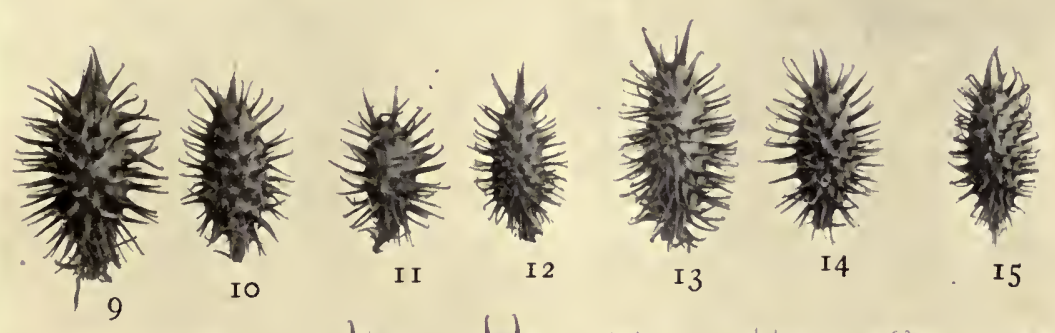

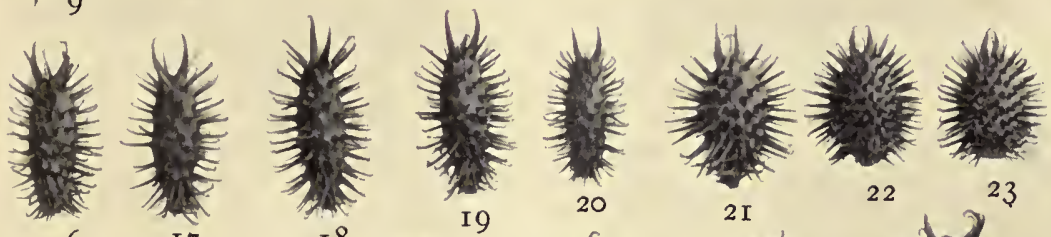

${ }^{16}{ }_{24}^{18}$

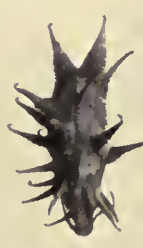

33

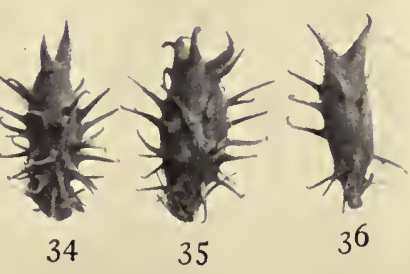

34

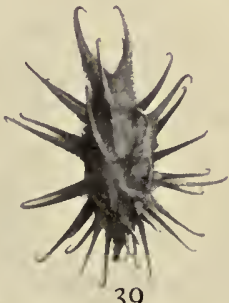

39
38

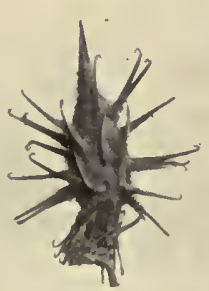

FRUITS OF XANTHIUM (Natural size) 
Lf * . सर

UNMESSITY OF HLIKOIS

URBANA 

$\mathrm{X}$. inflexum Mack. and Bush.

F. I. Bush, I916 (Hb. Gray, type material).

F. 2. Engelmann (Hb. Mo. 8555I).

F. 3. Bush I806 (Hb. Mo. 85522).

F. 4. Bush 1806 (Hb. Gray).

$\mathrm{X}$. pennsylvanicum Wallr.

F. 5. Greene (Hb. Greene I9822; type of $X$. californicum Greene).

F. 6. Sanford (Hb. Greene 19819, type of $X$. acutum Greene).

F. 7. Reverchon 2589 (Hb. Mo. 85546).

F. 8. Suksdorf 1584 ( $\mathrm{Hb}$. Mo. 85374; cotype of $X$. affine Greene).

F. 9. Lansing 3532 ( $\mathrm{Hb}$. Field 346590$)$.

F. Io. Heller 7550 (Hb. N. Y.).

$X$. calvum Millsp. and Sherff.

Ff. II and I2. Baker I760 (Hb. Calif. I31236, type).

$\mathrm{X}$. palustre Greene.

F. I3. Greene (Hb. Greene 19834, type material).

F. I4. Greene (Hb. Greene 19833, type material).

F. 15. Walker 973 (Hb. Calif. I28022).

X. australe Millsp. and Sherf.

F. I6. Palmer 275 (Hb. U. S. 463216 , type).

F. 17. Dr. Mertens, Valparaiso, Chile (ex Hb. Acad. Petrop., in Hb. Gray).

F. I8. Morong 807 (Hb. N. Y.):

X. echinatum Murr.

F. 19. Sturtevant (Hb. Mo. 85500).

F. 20. Victorin 1056 (Hb. Gray).

F. 21. Miss M. E. Blatchford, Prouts Neck, Me., Sept., I898 (Hb. Gray).

X. acerosum Greene.

F. 22. J. H. Schuette, Baird's Creek, Preble, Brown County, Wis., Sept. 26, 1899 (Hb. Gray).

F. 23. Burnham 28 (Hb. Gray).

F. 24. Lunell 80 (Hb. Gray).

X. italicum Mor.

F. 25. Suksdorf 1583 ( $\mathrm{Hb}$. Field 8975I, cotype of $X$. varians Greene).

F. 26. Macoun II4I5 ( $\mathrm{Hb}$. Can. II4I5, type of $X$. Macounii Britton).

F. 27. Macoun I0910 (Hb. Can. I09ro, type material of $X$. glanduliferum Greene).

F. 28. Sherff 3081 (Hb. Field 480739, matching fruits on Moretti's specimen in Hb. De Candolle).

F. 29. Bruyas, gravelly fields along banks of the Arc River, Aix Bouches-duRhone, France, Sept. 27, 1884 (Hb. Field 331608).

F. 30. Rose and Fitch I7507 (Hb. U. S. 760583). 


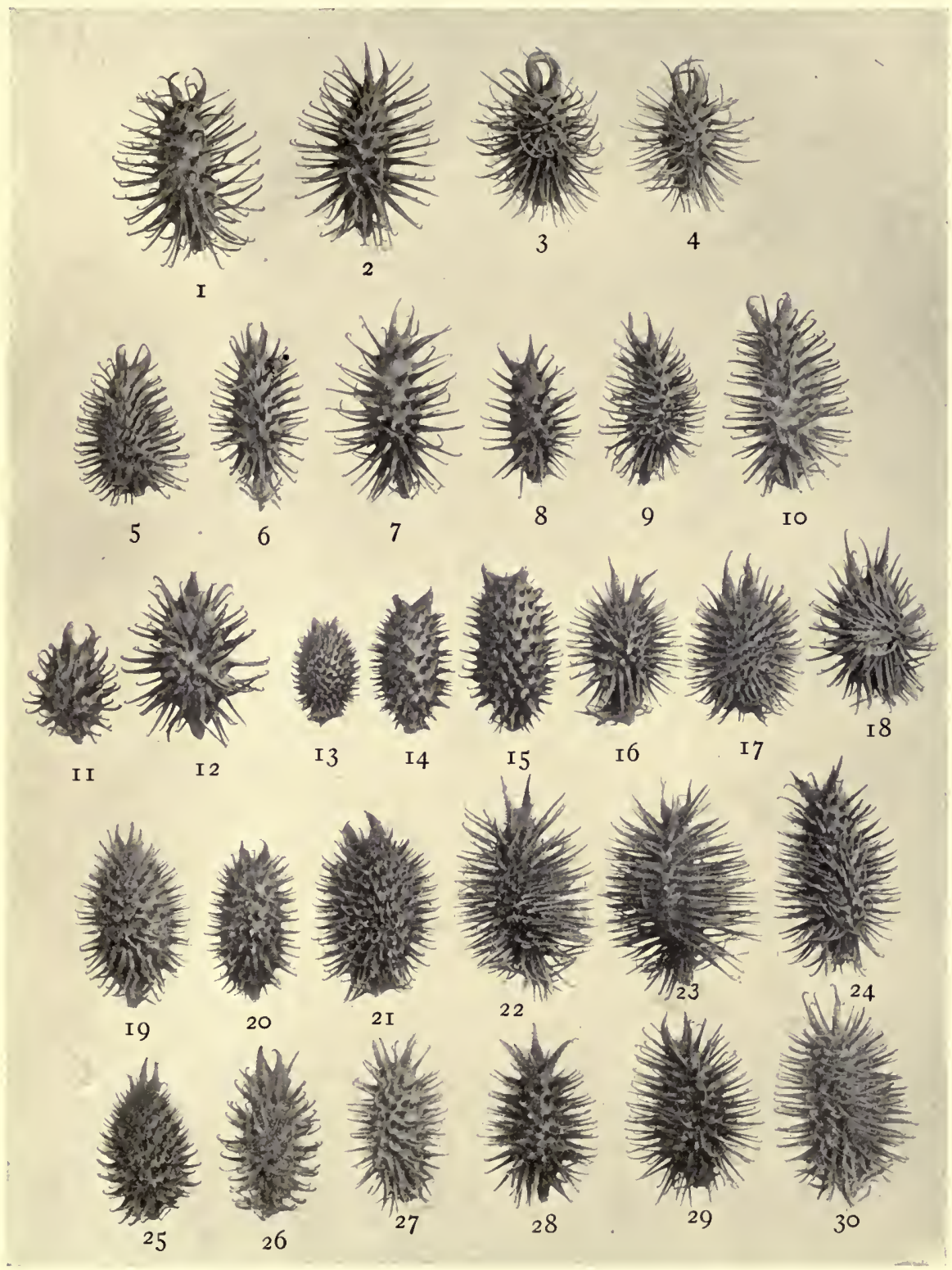

FRUITS OF XANTHIUM (Natural Size) 
LIM a ARY

UNIVERSITY OF ILLINOIS

URBANA 



\section{THE LIBRARY OF THE}

\section{JL'L 241943 \\ UUIVERSITY OF ILLINOIS}

X. oviforme Wallr.

Plate X.

F. I. Suksdorf (Hb. Field 211249 , cotype of $X$. silphiifolium Greene).

F. 2 and 3. Suksdorf 189 ( $\mathrm{Hb}$. Gray, topotype of $X$. silphiifolium Greene).

X. speciosum Kearn.

F. 4 and 6. Bush II 85 (Hb. Mo. 85380 , type material of $X$. bubalocarpon

F. 5. Kearney 785 (Hb. N. Y.; cotype).

X. campestre Greene.

F. 7. Greene (Hb. Greene I9837, type; an atypic bur on lower part of plant; burs higher up on type are more as in f. 8).

F. 8. Heller I I629 (Hb. Gray, topotype). 


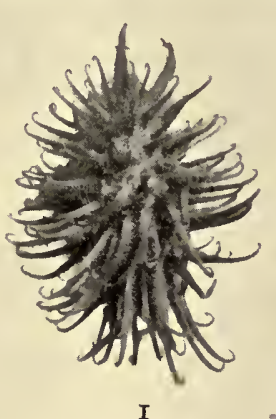

I

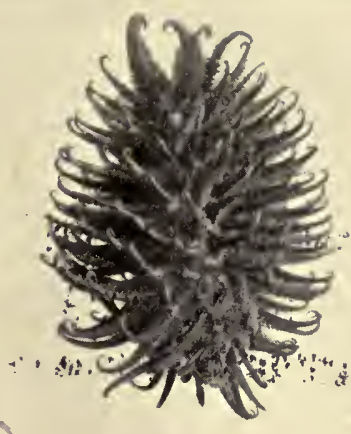

2

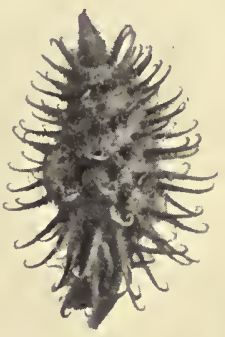

3

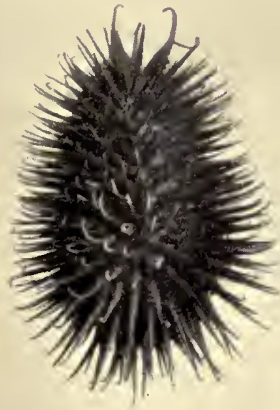

4

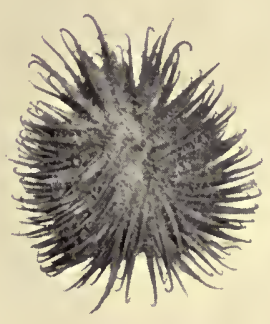

5

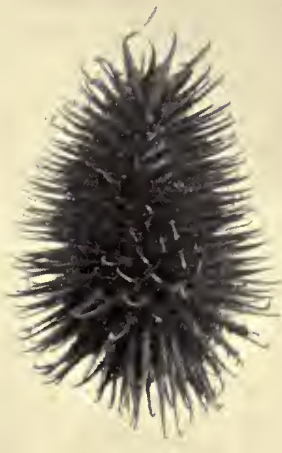

6

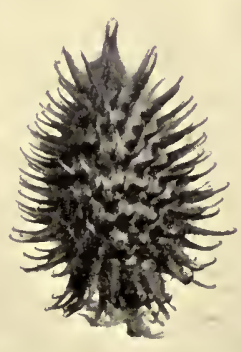

7

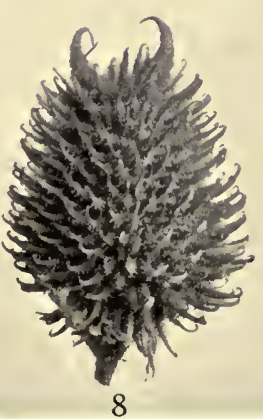

8

FRUITS OF XANTHIUM (Natural size 
LIPRAARY

UNIVESSITY OF ILLINOIS

URBANA 


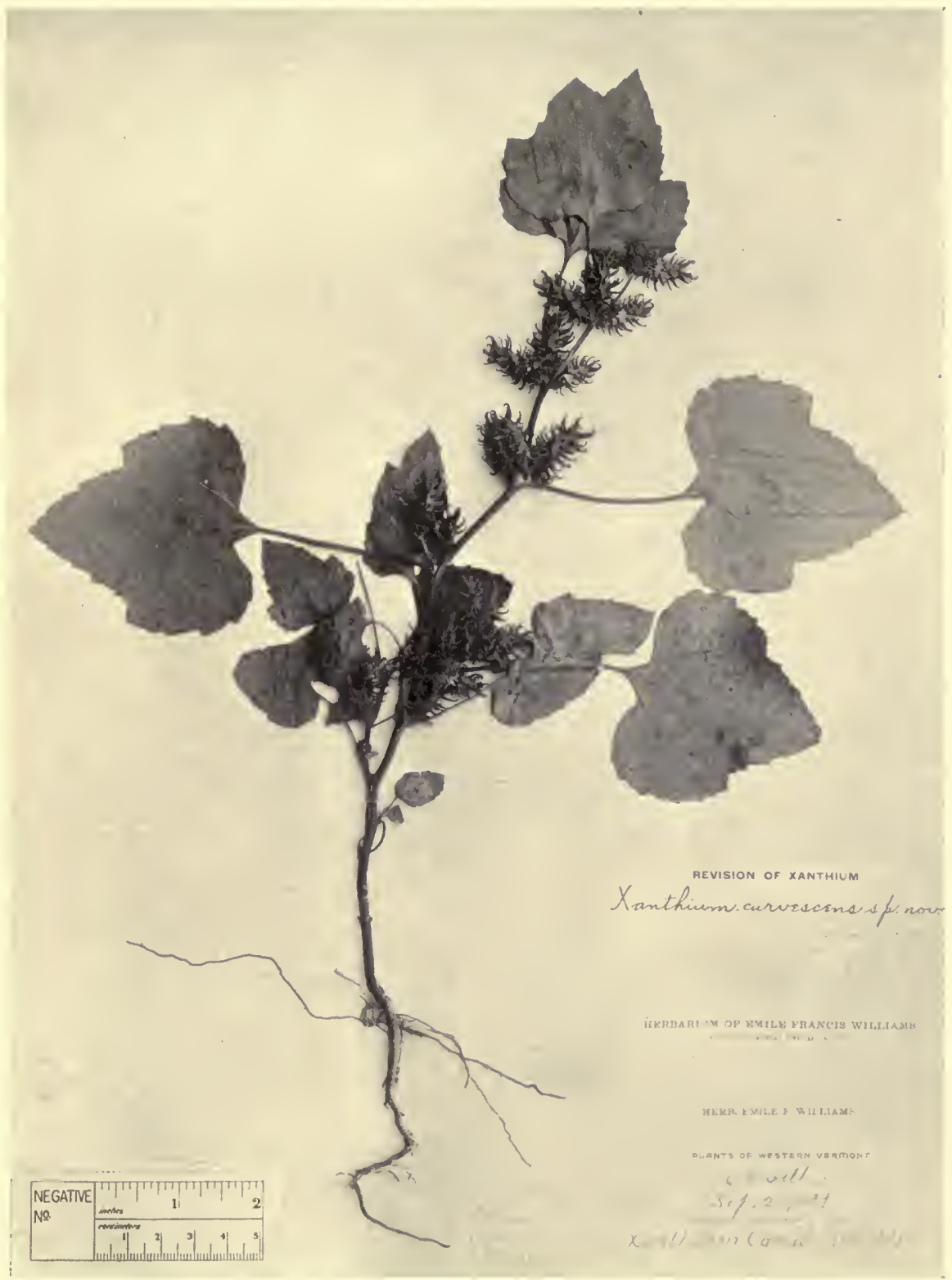

XANTHIUM CURVESCENS 
UERAB

UNIVERSITY OF ILLINOI3

URBANA 

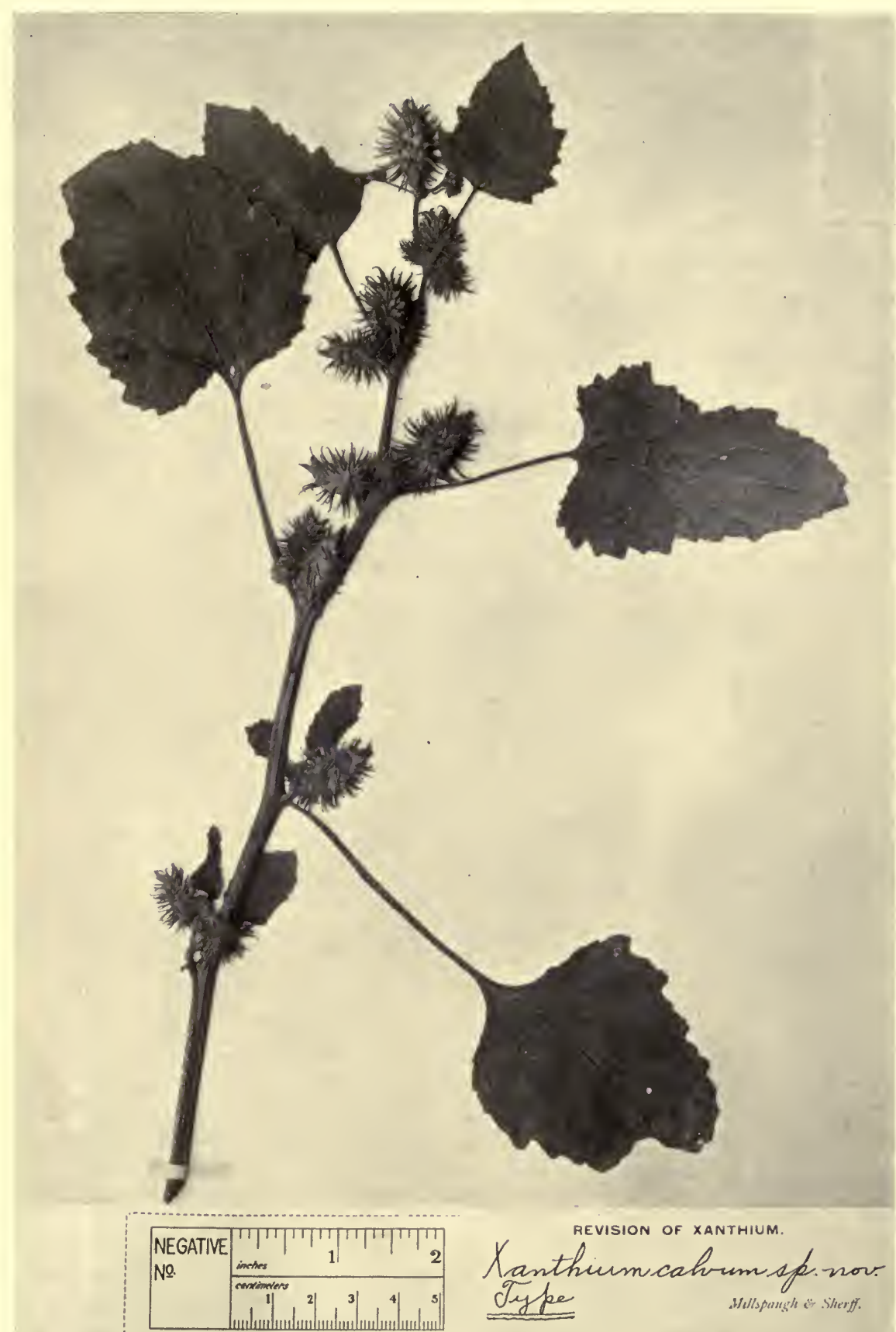

ST.PHEEMUYTARY

PLANTS OF THE PACIFIC COAST

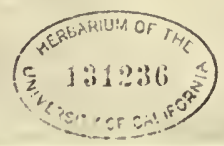

Distributes by C. F. BAKEN

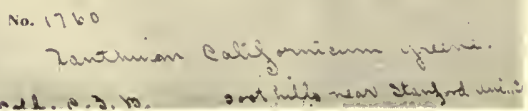


LPRARY

URIVERSIT of ILLINOIS

URBANA 


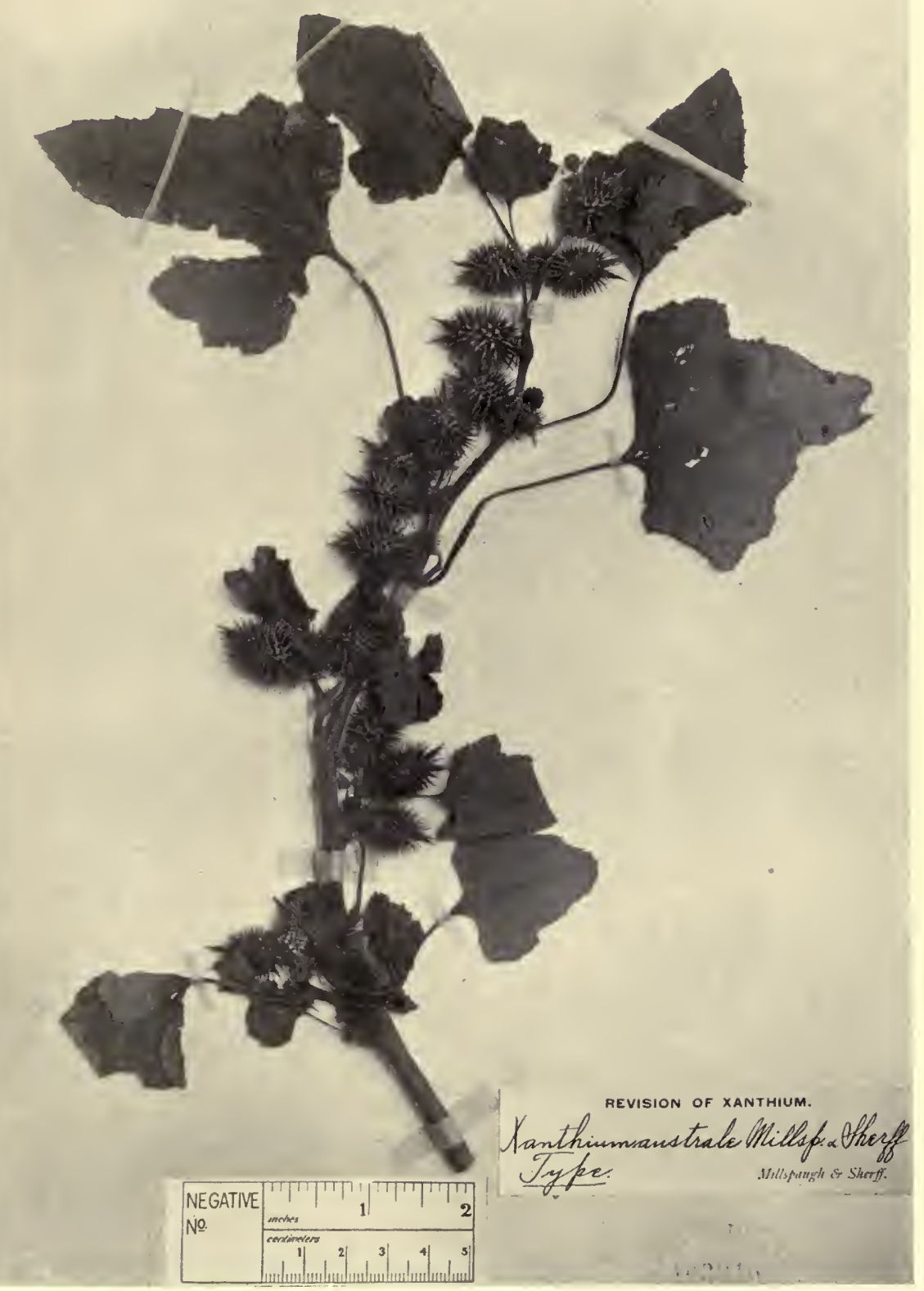

XANTHIUM AUSTRALE 
LPi. . .

UMIVERSITY OF ILLINOIS

URBANA 






